\title{
Liquid Chromatography in Studying Lipophylicity and Bioactivity of Pesticides
}

\author{
Małgorzata Janicka \\ Department of Physical Chemistry, Faculty of Chemistry, \\ Maria Curie-Skłodowska University, Lublin
}

Poland

\section{Introduction}

During the past decades the interest of new bioactive compounds for applications in medicine or agriculture has increased dramatically (Gocan \& Cimpan, 2005; Kaliszan, 1987; Kaliszan, 1992; Krieger et al., 2001; Lipiński et al, 2001; Nasal et al., 2003; Sangster, 1997). Physicochemical properties of new bioactive compounds like pesticides, such as solubility, lipophylicity (hydrophobicity), stability and acid-base character, should be determined in the early stages of development. These properties affect absorption, distribution and transport of xenobiotics in biological systems. The hydrophobic effect is assumed to be one of the driving forces for the passive transport of xenobiotics through bio-membranes and to a certain degree responsible for interactions with receptor.

The expressions "lipophylicity" and "hydrophobicity" are frequently used as synonymous, but in scientific use their meaning should be distinguished. According to IUPAC suggestions (Pliška et al., 1996) hydrophobicity means the association of nonpolar species in aqueous environment arising from the tendency of water to exclude nonpolar molecules. Lipophylicity as a measure of relative affinity of a molecule for a lipophylic environment has a broader meaning than hydrophobicity because may be connected with polar interactions.

Lipophylicity as a property determining biological activity of substance was firstly recognized by Overton, Meyer and Baum (Kaliszan, 1987; Kaliszan, 1992). During the time hundreds of articles, among them some review papers, of lipophylic properties of different bioactive compounds in medicine, agriculture or environmental chemistry have appeared (Héberger, 2007; Kah \& Brown, 2008; Komsta et al., 2010; Poole \& Poole, 2003; Valkó, 2004; Wang et al., 1999; Sherma, 2003).

Lipophylicity is commonly measured by solute distribution in biphasic liquid system and universal lipophylicity scale is formed by the logarithms of partition coefficients $(\log P)$ in the case of neutral species or distribution ratio $(\log \mathrm{D})$ for ionisable compounds (Kah \& Brown, 2008; Pliška et al., 1996). In early seventies octanol-water was proposed as reference system for lipophylicity measurements and to this day it remains as a standard for experimental and theoretical investigations. Due to experimental limitations connected with direct measurements of $\log \mathrm{P}(\log \mathrm{D})$ parameters by shake-flask method, chromatographic techniques are getting more and more popular in studying lipophilic properties of organic substances. Though partition parameters produce more universal scale of lipophylicity, 
chromatographic approach is much more convenient, reproducible, fast and inexpensive. The shake-flask and liquid chromatography procedures are now standardized and officially recommended by the Organization of Economic Co-operation and Development (Guidelines for the Testing of Chemicals) (Nasal et al., 2003).

\section{Theoretical background}

The application of liquid chromatography in lipophylicity determination follows from the definition of retention factor $\mathrm{k}$ :

$$
\mathrm{k}=\frac{\mathrm{n}_{\mathrm{s}}}{\mathrm{n}_{\mathrm{m}}}=\frac{\mathrm{c}_{\mathrm{s}}}{\mathrm{c}_{\mathrm{m}}} \frac{\mathrm{V}_{\mathrm{s}}}{\mathrm{V}_{\mathrm{m}}}
$$

where $\mathrm{n}$ is the average number of solute molecules while $\mathrm{c}$ is solute concentration at equilibrium, in the stationary and mobile phase, respectively; $\mathrm{V}_{\mathrm{s}}$ and $\mathrm{V}_{\mathrm{m}}$ are volumes of stationary and mobile phases. Introducing the phase ratio $\phi$ equal to $V_{s} / V_{m}$ and taking into account the definition of partition coefficient $\mathrm{K}$ referring to Nernst's law:

$$
\mathrm{K}=\frac{\mathrm{c}_{1}}{\mathrm{c}_{2}}
$$

where $\mathrm{c}$ is the concentration of neutral form of molecules in two immiscible solvents 1 and 2 at equilibrium, we can write:

$$
\log \mathrm{k}=\log \mathrm{K}+\log \phi
$$

Collander (Kaliszan, 1987) formulated the equation relating partition coefficients determined in different water-organic solvent systems:

$$
\log \mathrm{P}_{\mathrm{a}}=\mathrm{m} \log \mathrm{P}_{\mathrm{b}}+\mathrm{n}
$$

In equation 4 constants $\mathrm{P}_{\mathrm{a}}$ and $\mathrm{P}_{\mathrm{b}}$ are partition coefficients corresponding to two different systems: water-solvent a and water-solvent $\mathrm{b}$. As it was already observed by Collander, the fit of equation 4 depended on the polarity differences between organic solvents $a$ and $b$.

The combination of equations 3 and 4 leads to fundamental relationship in chromatographic determination of partition coefficient:

$$
\log \mathrm{P}_{\mathrm{a}}=\mathrm{p} \log \mathrm{k}+\mathrm{q}
$$

where regression coefficients $\mathrm{p}$ and $\mathrm{q}$ should be evaluated for a set of structurally related standard substances.

Important advantage of chromatographic measurements is that partition coefficient can be evaluated independently of impurities and without quantitative analysis. Apart from that reversed-phase liquid chromatography is simple, rapid and relatively inexpensive, requires a much smaller amount of tested solute than shake-flask method and is free of some practical complications like formation of stable emulsions. In spite of all advantages there are important limitations of chromatographic measurements. Reversed-phase chromatographic system is only a partial and incomplete model for octanol-water partitioning. In contrary to liquid-liquid system in reversed-phase chromatography, apart 
from interactions appearing in the bulk phase (solute-water, solute-organic solvent, waterorganic solvent, water-water, organic solvent-organic solvent), different interactions in stationary phase occur: solute-stationary phase, water-stationary phase, and organic solvent-stationary phase. Moreover, specific interactions (e.g. ion-exchange) with residual silanol groups at the surface can appear as well as pore size effects such as size or ion exclusion (Kaliszan, 1987; Nasal et al., 2003). Next complications are connected with reproducibility of results on columns or chromatoplates delivered by various producers or even from different batches of the same manufacturer. The dissimilarities between chromatographic and shake-flask partition coefficients result also from problems with accurate measurements of the dead volume in column technique (Poppe, 1993) or thin-layer effects in planar chromatography (Nurok, 1989). Summarizing the above considerations it should be emphasized that chromatographic parameters depend not only on solute but also mobile and stationary phases properties and don't form universal scale of lipophylicity, which is limited for structurally diverse substances.

Kaliszan (Kaliszan, 1987) and Gocan and Cipman, 2005 (Gocan \& Cipman, 2005) described in details first efforts and the history of applying liquid chromatography, thin-layer and column, for lipophylicity measurements. In the early studies stationary phases were impregnated with n-octanol and developed with mobile phases (aqueous or buffer solutions of organic modifiers) saturated with n-octanol. Such chromatographic systems resembled noctanol-water (buffer) partitioning and many researchers obtained very good linear correlations between chromatographic parameters and experimental $\log \mathrm{P}$ values. Due to technical inconvenience these methods are rarely used at present. Interesting results were described by Kaune et al. (Kaune et al., 1998) who investigated a group of commercial strazine herbicides and some of their degradation products using octadecyl column (LiChrospher 100, RP-18) coated with n-octanol and the buffer ( $\mathrm{pH}$ 7.5) saturated with noctanol as the mobile phase. Chromatographic partition coefficients were correlated to literature data (Figure 1) and, in comparison to gradient results obtained on LiChrospher

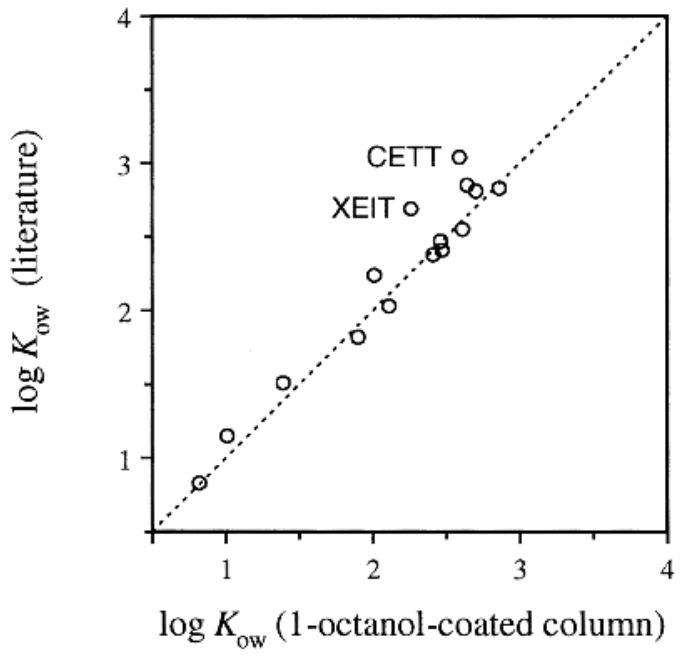

Fig. 1. Comparison between literature n-octanol-water partition coefficients and estimated by n-octanol-coated column method. (Kaune et al., 1998). 
100 RP-18e with nonlinear water-methanol gradient, proved to be better lipophylicity indices characterized by an excellent reproducibility. Currently Sirius Analytical Instruments Ltd. offers the instrument called ProfilerLDA [http://www.siriusanalytical.com.] for determination of lipophylicity ( $\log D)$ on HPLC columns dynamically coated with n-octanol and mobile phases buffered at desired $\mathrm{pH}$ value.

Spectacular increase of interest of applying chromatographic techniques in lipophylicity measurements was directly connected with introduction commercially available chemically bounded stationary phased commenced in the seventies of the last century. Reversed-phase stationary phases based on silica gel are stable, apolar and, similarly to biosystems, anisotropic (Kaliszan, 1987; Nasal et al., 2003).

For majority of substances it's extremely difficult to measure retention parameter for water (or buffer) as the mobile phase on apolar chemically bounded stationary phase. Due to general elution problem and long retention times, it's possible for moderately lipophylic solutes only. Moreover, water doesn't moisten most of RP layers and such experiments need forced flow, i.e., column or over-pressured-layer not thin-layer chromatography (Tyihák \& Mincsovics, 2001).

In liquid chromatography the key lipophylicity parameter is retention factor $\log \mathrm{k}$ or retention factor extrapolated to pure water $\log \mathrm{k}_{\mathrm{w}}$. In HPLC the value of $\log \mathrm{k}$ can be evaluated directly from chromatographic data, i.e. retention volume $\left(V_{R}\right)$ or time $\left(t_{R}\right)$ according to the following equations:

$$
\begin{gathered}
\mathrm{k}=\frac{\mathrm{V}_{\mathrm{R}}-\mathrm{V}_{\mathrm{o}}}{\mathrm{V}_{\mathrm{o}}} \\
\mathrm{k}=\frac{\mathrm{t}_{\mathrm{R}}-\mathrm{t}_{\mathrm{o}}}{\mathrm{t}_{\mathrm{o}}}
\end{gathered}
$$

where $V_{o}$ and $t_{o}$ are the dead volume or the dead time, respectively.

In planar chromatography solute retention is described by retardation factor $R_{F}$ equivalent to the ratio of the distance migrated by the solute zone to the distance moved by the solvent front and measured from the sample application position. In TLC practice the most frequently used is retention factor $R_{M}$ defined as:

$$
\mathrm{R}_{\mathrm{M}}=\log \frac{1-\mathrm{R}_{\mathrm{F}}}{\mathrm{R}_{\mathrm{F}}}
$$

The relationship existing between two factors, $\mathrm{k}$ and $\mathrm{R}_{\mathrm{F}}$ :

$$
\mathrm{k}=\frac{1-\mathrm{R}_{\mathrm{F}}}{\mathrm{R}_{\mathrm{F}}}
$$

leads to the following equation:

$$
\mathrm{R}_{\mathrm{M}}=\log \mathrm{k}
$$

Both factors, $\log k$ and $R_{M}$, are used alternatively, but in general $R_{M}$ parameter is still in use in thin-layer chromatography.

Isocratic $\log \mathrm{k}$ values are hardly ever applied as lipophylicity descriptors. These values strongly depend not only on stationary phase but also mobile phase organic modifier. The 
functions describing the effect of organic modifier concentration in the effluent on retention parameters can cross each other for particular organic solvents. Nevertheless, some interesting results were described by Yamagami and Katashiba (Yamagami \& Katashiba, 1996) who studied phenyl N-methyl and phenyl N.N-dimethyl carbamates using Capcell Pak C18 column (Shiseido, Japan) and buffered methanol as the mobile phase and obtained the best linear relationships $\left(\mathrm{R}^{2}=0.987-0.997\right)$ between $\log \mathrm{k}$ and experimental $\log \mathrm{P}$ parameters for $50 \%$ concentration of methanol in the effluent. De Kock and Lord (De Kock \& Lord, 1987) received almost equally good results $\left(\mathrm{R}^{2}=0.95\right)$ for polychlorinated biphenyls applying 20\% methanol in water on Resolve C18 (Waters) column. Ellgehausen et al. (Ellgehausen et al., 1981) correlated HPLC and TLC retention parameters of twenty commercial pesticides with partition coefficients log P. Xia et al. (Xia et al., 2005) obtained very interesting results on a new type of stationary phases, i.e. polystyrene-octadeceneencapsulated zirconia (C-18-PS- $\mathrm{ZrO}_{2}$ ) in column technique. The authors examined retention of eighteen newly synthesized benzoylphenylureas on C-18-PS- $\mathrm{ZrO}_{2}$ and commercial Kromasil C-18- $\mathrm{SiO}_{2}$ columns using water-methanol as effluent. Four aqueous solutions containing $80 \%, 85 \%, 90 \%$ and $95 \%$ of methanol were applied. Very good linear correlations $(\mathrm{R}>0.97)$ between retention coefficients $\log \mathrm{k}$ and structural descriptors (FHF, ECCR, $\mathrm{HOMO}, \mathrm{LUMO}, \mathrm{DM}, \mathrm{CMR}$ and $\mathrm{C} \log \mathrm{P}$ ) were obtained, especially for the new C-18-PS- $\mathrm{ZrO}_{2}$ stationary phase.

Xu et al. (Xu et al., 1999) described the results obtained by HPLC technique with soil column and aqueous methanol, for eight commercial pesticides (fungicides, insecticides and one herbicide). They applied column chromatography for indirect evaluation of soil organic partition coefficients $\left(K_{\mathrm{oc}}\right)$. As chromatographic lipophylicity indices there were used retention factors obtained for particular mobile phase compositions (log k) as well as $\log \mathrm{k}_{\mathrm{w}}$ parameters linearly extrapolated to pure water. The authors observed very high linearity between retention factors and literature $\log \mathrm{K}_{\mathrm{oc}}$ parameters ( $\mathrm{R}$ in the range 0.9784-0.791). Similar investigations were described by Bermúdez-Sadaña et al. (Bermúdez-Sadaña et al., 2006) who summarized results obtained on different columns: ODS, RP-CN or natural and artificial soils. Retention parameters of 48 substances, mainly pesticides, were used for indirect determination of soil-sorption coefficients $\mathrm{K}_{\mathrm{oc}}$. The authors considered the model proposed as a practical, alternative approach to estimating soil-sorption coefficients, though some deviations were observed for low retained compounds.

Pesticides mobility through soil structures can be investigated by thin-layer chromatography as well. Such experiments were performed by Ravanel et al. (Ravanel et al., 1999) on different types of soils and water or water-methanol mobile phases, and by Mohammad et al. (Mohammad et al., 2001) on silica, soil or mixed layers containing soil (silica, alumina and cellulose) with different mobile phases (aqueous ammonium or sodium salt solutions, with or without surfactant, aqueous surfactant or pure organic solvents).

The parameter most often applied as lipophylicity descriptor is retention factor extrapolated to pure water (or buffer) as the mobile phase, usually expressed as $\log k_{\mathrm{w}}$ (or $\mathrm{R}_{\mathrm{M} 0}$ in TLC). The value of $\log k_{w}$ is calculated by extrapolation of experimental retention function, i.e. $\log$ k vs. $\varphi$, where $\varphi$ is the concentration (volume fraction) of organic modifier in the effluent, towards pure water $(\varphi=0)$. The results of calculations strongly depend on the range of extrapolation, i.e. the range of organic modifier concentration in the bulk phase, but also on mathematical formula applied for the purpose. The simplest description results from Soczewiński-Wachtmeister's equation (Kaliszan, 1987; Sangster, 1997): 


$$
\log \mathrm{k}=\log \mathrm{k}_{\mathrm{w}}-\mathrm{s} \varphi
$$

where s, the slope of the experimental data after fitting to regression model, is related to specific hydrophobic surface are of the solute.

Within the intermediate range of organic modifier in the effluent an approximate linear relationship between $\log \mathrm{k}$ and $\varphi$ almost always is found. The majority of log $\mathrm{k}$ vs. $\varphi$ plots are curved for mobile phases "rich" in water. Therefore quadratic equations are also proposed to describe the effect of mobile phase composition on log k values:

$$
\log \mathrm{k}=\log \mathrm{k}_{\mathrm{w}}-\mathrm{a}_{1} \varphi-\mathrm{a}_{2} \varphi^{2}
$$

where $\mathrm{a}_{1}$ and $\mathrm{a}_{2}$ are regression constants without physical significance (Gocan \& Cipman, 2005).

Schoenmakers et al. (Kaliszan, 1987) proposed the following equation describing almost entire range of organic solvent concentration in the mobile phase:

$$
\ln \mathrm{k}=\ln \mathrm{k}_{\mathrm{w}}+\mathrm{A} \varphi^{2}+\mathrm{B} \varphi+\mathrm{C} \sqrt{\varphi}
$$

Deviations from linearity of equation 13 are observed for higher than $90 \%$ concentration of organic modifier in water. According to results obtained by Pietrogrande et al. (Pietrogrande et al., 1985) retention factors calculated according to eq. 13 weakly correlate with $\log P$ values so they don't find application in practice.

The available evidence demonstrate that $\log k_{w}$ values calculated according to equations 11 or 12 differ significantly. Moreover extrapolated retention parameter depends on organic modifier that is in contrary with its physical significance. Some scientist recognize this parameter as an unacceptable lipophylicity descriptor, but majority considerate the extrapolation as a convenient method of standardization of chromatographic data (Gocan \& Cipman, 2005; Kaliszan, 1987).

In our investigations we proposed new, alternative to extrapolation method of calculation of $\log \mathrm{k}_{\mathrm{w}}$ parameters [Janicka, 2009; Janicka et al., 2000). This numerical method, originating from thermodynamic description of the system solute-stationary phase-solution (Jaroniec, 1993), uses the following linear form of Ościk's equation:

$$
\mathrm{G}\left(\mathrm{x}_{\text {org }}\right)=\frac{\mathrm{x}_{\text {org }}\left(1-\mathrm{x}_{\text {org }}\right)}{\log \mathrm{k}-\mathrm{x}_{\text {org }} \log \mathrm{k}_{\text {org }}-\left(1-\mathrm{x}_{\text {org }}\right) \log \mathrm{k}_{\mathrm{w}}}=a x_{\text {org }}+\mathrm{b}
$$

where $x_{o r g}$ is a molar fraction of organic modifier in aqueous mobile phase and $\log k_{\text {org, }} \log$ $\mathrm{k}_{\mathrm{w}}$ and $\log \mathrm{k}$ are solute retention parameters corresponding to pure organic modifier, water and binary mixture as the mobile phase, respectively; $a$ and $b$ are regression factors. In the method the values of $\log \mathrm{k}_{\mathrm{org}}, \log \mathrm{k}$ and $\mathrm{x}_{\mathrm{org}}$ are known (experimentally evaluated) and $\log$ $\mathrm{k}_{\mathrm{w}}$ parameter is determined by numerical fitting to equation 14 to obtain the linearity between the left term denoted as $G$ and $x_{\text {org }}$. We tested numerical method for different groups of substances, using various mobile and stationary phases by thin-layer, overpressured-layer and column reversed-phase chromatography techniques [Janicka, 2003; Janicka et. al., 2004; Janicka et al. 2004; Janicka et al., 2006; Janicka, 2007) and numerical log $\mathrm{k}_{\mathrm{w}}$ parameters proved to be very good lipophylicity descriptors linear correlated to experimental and calculated $\log \mathrm{P}$ values and moreover, in contrary to extrapolated, almost independent of the range of organic modifier concentration in the effluent. 
In order to introduce the next chromatographic lipophylicity parameter one should return to equation 11. The value of parameter s, regression coefficient of this equation, is characteristic for chromatographed solute. Biagi et al. (Biagi et al., 1994) observed linear relationships between extrapolated $\log \mathrm{k}_{\mathrm{w}}$ values and $\mathrm{s}$ parameters for congeneric substances and, similarly to Waterbeemd et al. (Waterbeemd et al., 1996), designated the ratio equal to s/log $\mathrm{k}_{\mathrm{w}}$ as lipophylicity descriptor, alternative to $\log \mathrm{k}_{\mathrm{w}}$, for closely related substances. Moreover the linearity between these two parameters is a measure of congenerity of solutes tested.

Valkó and Slegel (Valkó \& Slegel, 1993) introduced new hydrophobicity index $\varphi_{0}$ defined as:

$$
\varphi_{\mathrm{o}}=\frac{\log \mathrm{k}_{\mathrm{w}}}{\mathrm{s}}
$$

According to equation $11 \varphi_{\mathrm{o}}$ is a volume fraction of organic modifier in the mobile phase at which solute retention factor $\mathrm{k}$ is equal to 1, i.e. molar concentrations of solute molecules in stationary and mobile phases are equal to each other (equation 1) or a volume fraction required to get the substance retention time exactly twice of the dead time (equation 7). Important advantage of $\varphi_{\mathrm{o}}$ is that it's not only a parameter of adjustment but it has physical interpretation and, for majority of substances can be measured experimentally. According to Valkó and Slegel $\varphi_{\mathrm{o}}$ parameters evaluated for different organic modifiers correlate to each other as well as to experimental or calculated $\log \mathrm{P}$ values.

Taking into account different lipophylicity parameters determined by isocratic reversephase liquid chromatography one can improve the basic correlation equation 5 by:

$$
\log \mathrm{P}=\mathrm{p}_{1} \mathrm{~s}+\mathrm{q}_{1} \log \mathrm{k}_{\mathrm{w}}+\mathrm{r}_{1}
$$

or write another relationship:

$$
\log \mathrm{P}=\mathrm{d} \varphi_{\mathrm{o}}+\mathrm{e}
$$

\section{Isocratic HPLC}

Many researchers used isocratic reversed-phase liquid chromatography to measure lipophylic properties of bioactive compounds, also pesticides, both commercial and newly synthesized, using variety of mobile and stationary phases.

Braumann et al. (Braumann et al., 1983) compared log $\mathrm{k}_{\mathrm{w}}$ parameters linear extrapolated from water-methanol mobile phase with $\log \mathrm{P}$ values for a group of herbicides (phenylureas, s-triazines and phenoxycarbonic acid derivatives) and according to their suggestion chromatographic parameters may be a better model for the assessment of lipophylicity in biological system than $\log P$ values.

Hsieh and Dorsey (Hsieh \& Dorsey, 1995) studied seven pesticides (among a group of PAHs and barbiturates) on homemade C-18 columns with water-methanol mobile phase. Extrapolated retention factors $\log \mathrm{k}_{\mathrm{w}}$ were compared with biotransfer factor for beef and milk and gave much better linearity $\left(\mathrm{R}^{2}=0.852-0.887\right)$ than $\mathrm{n}$-octanol-water partition coefficients $\left(\mathrm{R}^{2}=0.501\right.$ and 0.584$)$.

Darwish et al. (Darwish et al., 1993) and Cserháti and Forgács (Cserháti \& Forgács, 1997)

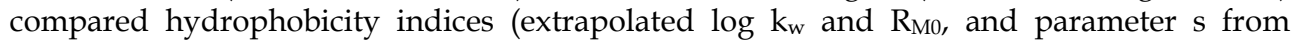
equation 11) of twelve pesticides (herbicides and fungicides) evaluated by TLC and HPLC 
on octadecylsilica stationary phase and water-methanol as the mobile phase. Principal Component Analysis (PCA) showed that chromatographic parameters from two techniques might be used alternatively. However, it was noticed that differences in biological activity of tested herbicides and fungicides couldn't be attributed to separate parameters (s and $\log \mathrm{k}_{\mathrm{w}}$ or $\mathrm{s}$ and $\mathrm{R}_{\mathrm{M} 0}$ ). Similar results were obtained by Zhang et al. (Zhang et al., 2000) who studied 37 commercial pesticides (insecticides, herbicides fungicides and growth regulators) by HPLC and TLC on ODS type stationary phases and water-methanol mobile phases. Lipophylicity was described by retention parameters extrapolated to pure water $\left(\log \mathrm{k}_{\mathrm{w}}\right.$ and $\mathrm{R}_{\mathrm{M} 0}$ ) and specific hydrophobic surface area ( $\mathrm{s}$ values). Linearity between $\log \mathrm{k}_{\mathrm{w}}\left(\mathrm{R}_{\mathrm{M} 0}\right)$ and $\mathrm{s}$ parameters obtained by HPLC $(R=0.9867)$ and TLC $(R=0.9790)$ confirmed both indices as alternative lipophylicity descriptors, but PC analyses showed that particular groups of pesticides, different in chemical structure and bioactivity, couldn't be distinguished from each other considering only chromatographic parameters.

Cserháti and Forgács (Cserháti \& Forgács, 1994) applied alumina support as stationary phases in HPLC and TLC techniques with n-hexane-dioxan as effluent for studying retention of 26 pesticides (commercial herbicides, fungicides, acaricides and insecticides). TLC and HPLC retention factors determined in the studies, though strongly intercorrelated, proved to have a negligible effect on the type of biological activity.

Pyka and Miszczyk (Pyka \& Miszczyk, 2005) studied lipophylic properties of nine urea pesticides. Chromatographic lipophylicity indices $\left(\log k_{\mathrm{w}}, \mathrm{R}_{\mathrm{M} 0}, \mathrm{~s}\right.$ and $\varphi_{\mathrm{o}}$ ) were compared with partition coefficients (five different values: experimental and calculated from molecular structures) and Gutman and Randić topological indices. In experiments HPLC (Econosphere C-18 column) and TLC (RP-18W plates) techniques were used with water-methanol as the mobile phase. Chromatographic lipophylicities were intercorrelated and the results $(R>0.99)$ indicated that studied pesticides could be regarded as compounds belonging to the same group. Very high linearity ( $\mathrm{R}$ in the range 0.8450-0.9924) was observed between chromatographic parameters ( $\log k_{w}, R_{M 0}, s$ and $\varphi_{o}$ ) and partition coefficients, especially for $\varphi_{o}$ calculated from HPLC. From all topological indices analysed in the studies only one, Gutman index $\mathrm{M}^{\prime}$, correlated well with chromatographic parameters and experimental $\log \mathrm{P}$ values $(\mathrm{R}>0.9)$.

Peculiar database are $\varphi_{\mathrm{o}}$ parameters collected by Valkó for different bioactive compounds (including thirty trade herbicides) and calculated from HPLC data (Brauman et al., 1983) obtained on C-18 column and acetonitrile as the mobile phase modifier.

Reversed-phase chromatography, both planar and column, is particularly attractive technique for studying new organic substances with potential or even defined bioactivity.

Perišić-Janjić et al. (Perišić-Janjić et al., 2001; 2003a; 2003b; 2005) applied planar chromatography to study lipophylic properties of newly synthesized s-triazine derivatives. These nitrogen-containing compounds are widely used as herbicides in agriculture and industry and some of them have fungicidal properties. In the TLC measurements there were used different stationary phases: silica gel impregnated with paraffin oil (Perišić-Janjić et al, 2003a), RP-18 (Perišić-Janjić et al, 2003b; Perišić-Janjić et al, 2005), RP- $\mathrm{NH}_{2}$ (Perišić-Janjić et al, 2005) and aminoplast and cellulose (Perišić-Janjić et al, 2001). Aqueous solutions of methanol, acetone, acetonitrile, dioxane, 2-propanol, tetrahydrofuran or methanol-dilute acetic acid were compared as mobile phases (Perišić-Janjić et al, 2001). Linear extrapolated $\mathrm{R}_{\mathrm{M} 0}$ parameters were compared with software calculated $\log \mathrm{P}$ values. In the studies the effect of mobile phase $\mathrm{pH}$ value on retention was used to calculate the approximate protonation constants $\mathrm{pK}_{\mathrm{a}}$ of tested substances. The values were correlated with Hammett substituent constants $\sigma$. 
In our studies homological s-triazines were investigated (Janicka et al., 2004) in TLC and OPLC technique with RP-8 and RP-18 stationary phases and water-acetone, wateracetonitrile, water-tetrahydrofuran and water-dioxane as mobile phases. We correlated linear extrapolated and numerical $\log \mathrm{k}_{\mathrm{w}}$ parameters with $\log \mathrm{P}$ values calculated from molecular structures of solutes. The results obtained allowed to select numerical $\log \mathrm{k}_{\mathrm{w}}$ parameters calculated from OPLC technique in water-acetonitrile as the best lipophylicidy descriptors of s-trazines. The same group of homological s-triazines was analyzed in HPLC technique (Janicka et al., 2006). In this case we applied RP-18e (Purospher) column with methanol or acetonitrile as organic modifiers. Chromatographic lipophylicities, $\log \mathrm{k}_{\mathrm{w}}$, calculated by linear and parabolic extrapolation and by numerical method were compared with different software calculated $\log P$ values. All $\log k_{w}$ parameters proved to be very good lipophylicity descriptors but the numerical seemed to be more universal (see Table 1).

\begin{tabular}{|c|c|c|c|c|c|c|c|c|c|c|c|c|c|}
\hline & & \multicolumn{2}{|c|}{$A \log P$} & \multicolumn{2}{|c|}{ IAlog $P$} & \multicolumn{2}{|c|}{$\operatorname{clog} P$} & \multicolumn{2}{|c|}{$\log P_{K o} W_{i n}$} & \multicolumn{2}{|c|}{$x \log P$} & \multicolumn{2}{|c|}{$\log P_{\text {Chem }}$. Off } \\
\hline & & $r$ & $S D$ & $r$ & $S D$ & $r$ & $S D$ & $r$ & $S D$ & $r$ & $S D$ & $r$ & $S D$ \\
\hline $\log k_{w}$ & 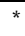 & 0.982 & 0.431 & 0.979 & 0.397 & 0.980 & 0.739 & 0.978 & 0.695 & 0.983 & 0.551 & 0.981 & 0.534 \\
\hline linear & ** & 0.943 & 0.766 & 0.939 & 0.676 & 0.935 & 1.311 & 0.943 & 1.109 & 0.934 & 1.083 & 0.946 & 0.893 \\
\hline $\log \mathrm{k}_{\mathrm{w}}$ & * & 0.970 & 0.561 & 0.927 & 0.740 & 0.980 & 0.736 & 0.980 & 0.663 & 0.978 & 0.626 & 0.986 & 0.456 \\
\hline parabolic & ** & 0.949 & 0.729 & 0.933 & 0.706 & 0.935 & 1.317 & 0.946 & 1.081 & 0.933 & 1.095 & 0.949 & 0.870 \\
\hline $\log k_{w}$ & * & 0.987 & 0.370 & 0.945 & 0.645 & 0.996 & 0.332 & 0.996 & 0.288 & 0.993 & 0.359 & 0.996 & 0.246 \\
\hline numerical & ** & 0.985 & 0.396 & 0.955 & 0.586 & 0.995 & 0.377 & 0.995 & 0.333 & 0.988 & 0.472 & 0.993 & 0.327 \\
\hline
\end{tabular}

* - methanol as organic modifier; ${ }^{* *}$ - acetonitrile as organic modifier

Table 1. Correlation matrix of $\log k_{w}$ vs. $\log P$ relationships. (Janicka et al., 2006).

Different scientists investigated new thiobenzanilides, substances with strong antibacterial or antimycotic activity. In the studies reversed-phase planar (Janicka et al., 2000; Matysiak et al., 1999; Janicka, 2006) and column (Niewiadomy et al., 1998; Jóźwiak, 2000; Jóźwiak et al., 2000) chromatography was applied. In TLC RP-8, RP-18 and RP-CN stationary phases and water-methanol or water-acetone as effluents were used, while in HPLC RP-18e (Eurosil Bioselect) or IAM stationary phases and buffered methanol $(\mathrm{pH} 4)$ or acetonitrile were applied as the mobile phases. As lipophylicity descriptors were analysed $\log \mathrm{k}_{\mathrm{w}}$ parameters, linearly extrapolated or numerical and/or $\varphi_{\mathrm{o}}$ values. Chromatographic lipophylicities were compared not only with calculated $\log \mathrm{P}$ values but also with biological activities (described by minimal inhibitory concentration, MIC) against different dermatophytes, yeasts and moulds, giving very good results.

Djaković-Sekulić et al. (Djaković-Sekulić et al., 1987) evaluated lipophylic properties of potential pesticides, i.e. ten anilides (formanilide and 4-substituted acetanilides) using TLC technique with starch and cellulose and different mobile phases. Linear extrapolated $R_{M 0}$ parameters were correlated with calculated $\log \mathrm{P}$ values giving excellent parabolic correlations. In the study very good linearity $(R=0.839-0.911)$ for multivariable regression equation $R_{M 0}=c_{1}+c_{2} \pi+c_{3} \sigma+c_{4} H B$, describing correlations between $R_{M 0}$ and molecular descriptors: Hansch parameters $\pi$, the Hammett electronic constant $\sigma$ and the hydrogenbond constant $\mathrm{HB}$, was obtained.

The same authors studied newly synthesized anilides (pivalanilides, benzanilides and $\alpha$ phenylacetanilides) using HPLC technique with LiChrosorb RP-18 column and watermethanol as the mobile phase (Djaković-Sekulić et al., 2001). Different chromatographic 
lipophylicity indices (linear extrapolated $\log \mathrm{k}_{\mathrm{w}}, \mathrm{s}$ and $\varphi_{\mathrm{o}}$ were correlated with calculated $\log$ $P$ values as well as with molecular indices (the Hammett electronic constant $\sigma$ and the hydrogen-bond constant $\mathrm{HB})$ giving very good linear relationships $(\mathrm{R}=0.936-0.985)$. The authors claimed: "more rational and objective estimation and comparison of hydrophobicity is possible by multiple regression. Hydrophobic and steric parameters taken into account in this way contribute to the QSAR paradigm." Experimental $\log \mathrm{k}_{\mathrm{w}}$ values were subsequently correlated with topological indexes by Djaković-Sekulić et al. (Djaković-Sekulić et al., 2003). Various scientists examined different groups of newly synthesized triazoles, well-known active compounds among others known as herbicides and fungicides. Perišić-Janjić et al. (Perišić-Janjić et al., 2000) studied ten 1,2,4-triazoles using HPLC and TLC techniques. In HPLC they applied RP-8 (Lichrosorb) and water-methanol and water-acetinitrile while in TLC silica gel impregnated with paraffin oil and water-methanol were used. Chromatographic lipophylicity indices (linear extrapolated $\log \mathrm{k}_{\mathrm{w}}$ and $\mathrm{R}_{\mathrm{M} 0}$ and $\varphi_{\mathrm{o}}$ ) were correlated with calculated $\log \mathrm{P}$ values giving very high linearity ( $\mathrm{R}$ in the range 0.928 0.996). In the studies relationships between chromatographic lipophylices and antimicrobial activity against Salmonella enteritidis was analysed. Better results were obtained for $R_{M 0}$ and $\varphi_{\mathrm{o}}$ than $\log \mathrm{k}_{\mathrm{w}}$, though deviation from linearity for some substances were observed. Sztanke et al. (Sztanke et al., 2008) studied a group of 14 derivatives of 1,2,4-triazoles potential fungicides, applying HPLC technique on ODS stationary phase (Supelcosil LC-18) with buffered dioxane ( $\mathrm{pH}$ 3.5). Unsatisfactory correlations between extrapolated $\log \mathrm{k}_{\mathrm{w}}$ parameters and calculated $\log \mathrm{P}$ values $(\mathrm{R}=0.6707)$ observed in the studies were explained by the weakness of computer program [Pallas 3.1.1.2, CampuDrug, 2003] in the case of ortho, meta and para chloro isomers.

Matysiak et al. (Matysiak et al. 2002) determined lipophylicity of new 2-arylbenzothiazoles with potential antimycotic properties applying TLC technique on RP-8 and RP-18W stationary phases with different effluents. The author obtained linear correlations between chromatographic lipophylicities (extrapolated $\mathrm{R}_{\mathrm{M} 0}$ and $\mathrm{s}$ ) and calculated $\log \mathrm{P}$ values and Hansch parameters $\pi$. The same authors (Matysiak et al., 2004) investigated antimycotic compounds belonging to 2-(2,4-dihydroxyphenyl)benzothiazoles by HPLC on RP-18 (LiChrosorb) stationary phase and buffered methanol as an effluent ( $\mathrm{pH} 4.0$ and 7.4). Chromatographic descriptors $\log \mathrm{k}_{\mathrm{w}}, \mathrm{s}$ and $\varphi_{\mathrm{o}}$ were compared with calculated $\log \mathrm{P}$ values and afterwards, with fungistatic properties expressed by $\log 1 / \mathrm{MIC}$.

Lipophylicities of nine newly synthesized N-hydroxyethylamides of aryloxyalkylene and piridine carboxylic acids were determined by Cipman et al. (Cipman et al., 1998) who applied TLC technique on RP-8 stationary phase and water-methanol effluent. Extrapolated $\mathrm{R}_{\mathrm{M} 0}$ parameters linearly correlated with calculated $\log \mathrm{P}$ partition coefficients ( $\mathrm{R}$ equal to 0.990 and 0.992) confirmed the significance of reversed-phase chromatography in determination of lipophylicity of congeneric compounds. Similar investigations were performed for propanoic acid amides by Djaković-Sekulić et al. (Djaković-Sekulić et al., 2002) who used silica gel impregnated by paraffin oil in TLC measurements. The authors additionally correlated extrapolated $\mathrm{R}_{\mathrm{M} 0}$ values with Hansch $\pi$ parameters. Similar results were obtained for for n-phenylsuccinimide derivatives (Perišić-Janjić et al., 2002), benzimidazoles (Perišić-Janjić \& Podunavac-Kuzmanović, 2008) or azaphenothiazines (Zięba \& Prus, 2009) - potential herbicides, fungicides or insecticides. Perišić-Janjić et al. (Perišić-Janjić et al., 2007) used TLC technique and RP-18 stationary phase and variety of mobile phases (aqueous solutions of methanol, ethanol, 1-propanol, 2-propanol, acetonitrile, 
acetone, tetrahydrofuran and dioxane) to determine lipophylic properties of eight 2phenylacetamide derivatives and obtained good correlations between $R_{\mathrm{M} 0}$ parameters and calculated $\log P$ values as well as with biological activity predictors.

Lipophylic properties of newly synthesized 2-(chlorophenoxy)acyl derivatives and naryltrichloroacetamides, potential herbicides, were examined by Janicka et al. (Janicka et al., 2004) by TLC technique on RP-18 stationary phase and buffered methanol as effluent ( $\mathrm{pH}$ 5.3, 7.3 and 8.3). As lipophylicity descriptors $\log \mathrm{k}_{\mathrm{w}}$ parameters calculated by linear extrapolation and numerical method were applied. The best linear correlations ( $\mathrm{R}^{2}$ equal to $0.8057,0.8084$ or 0.9811 ) were observed between numerical $\log \mathrm{k}_{\mathrm{w}}$ and calculated $\log \mathrm{P}$ parameters for mobile phases at $\mathrm{pH} 5.3$ or 8.3.

Kostecka et al. (Kostecka et al., 2006) studied lipophylic properties of 2,4dihydroxyphenylthioamide fungicides by TLC (RP-18/water-methanol) and HPLC (BDS C18 /water-methanol) techniques and their results confirmed $\log \mathrm{k}_{\mathrm{w}}, \mathrm{R}_{\mathrm{M} 0}$ and s parameters as alternative lipophylicity descriptors for structurally similar compounds. The relationships between fungicidal activity and experimental lipophylicity indicated the possibility of reversed-phase liquid chromatography to choose compounds suitable for microbiological investigations.

\section{Gradient RP HPLC}

Important disadvantage of isocratic liquid chromatography application in lipophylicity studies is connected with the time of analysis. This technique usually requires preliminary measurements to establish optimal separation conditions; the range of organic modifier concentration should be wide enough to obtain accurate retention parameters; for more lipophylic substances and long retention times the measurements are much extended. Shortening chromatographic columns or variations of effluent flow rates can partially solve this problem. Another advantages offer planar techniques: the possibility of simultaneous measurements for many substances and, in the case of OPLC applying the forced-flow, really shortened analysis time. But the most attractive solution is gradient elution for the high throughput estimation of lipohylicity parameters.

For a linear solvent strength gradient in RPLC the retention time $\left(t_{\mathrm{g}}\right)$ is related to isocratic parameters by the following equation (Gocan \& Cipman, 2005):

$$
\mathrm{t}_{\mathrm{g}}=\mathrm{C}+\left(\frac{\mathrm{t}_{\mathrm{M}}}{\mathrm{b}}\right) \log \mathrm{k}_{\mathrm{o}}
$$

where $t_{\mathrm{g}}$ is a gradient retention time, $\mathrm{t}_{\mathrm{M}}$ is the column hold-up time, $\mathrm{b}$ is a gradient steepness parameter, $\log k_{o}$ is the isocratic retention parameter for the system at the start of the gradient, $\mathrm{C}$ is complex system constant.

Valkó et al. (Valkó et al., 1997; Du et al., 1998) using fast gradient liquid chromatography introduced chromatographic hydrophobicity index (CHI) as an independent measure of hydrophobicity which can be correlated with $\log \mathrm{P}$. CHI is an extension of the concept of lipophylicity parameter $\varphi_{\mathrm{o}}$ (equation 15 ) to gradient elution. $\mathrm{CHI}$ can be evaluated from the following formula:

$$
\mathrm{CHI}=\mathrm{At}_{\mathrm{g}}+\mathrm{B}
$$


Parameters A and B are characteristic for given gradient system and can be evaluated for a series of standards with experimentally determined gradient retention times $t_{\mathrm{g}}$ and isocratic values of $\varphi_{\mathrm{o}}$. Equation 19 allows to calculate $\mathrm{CHI}$ parameter for any compound with measured gradient retention time $t_{g}$.

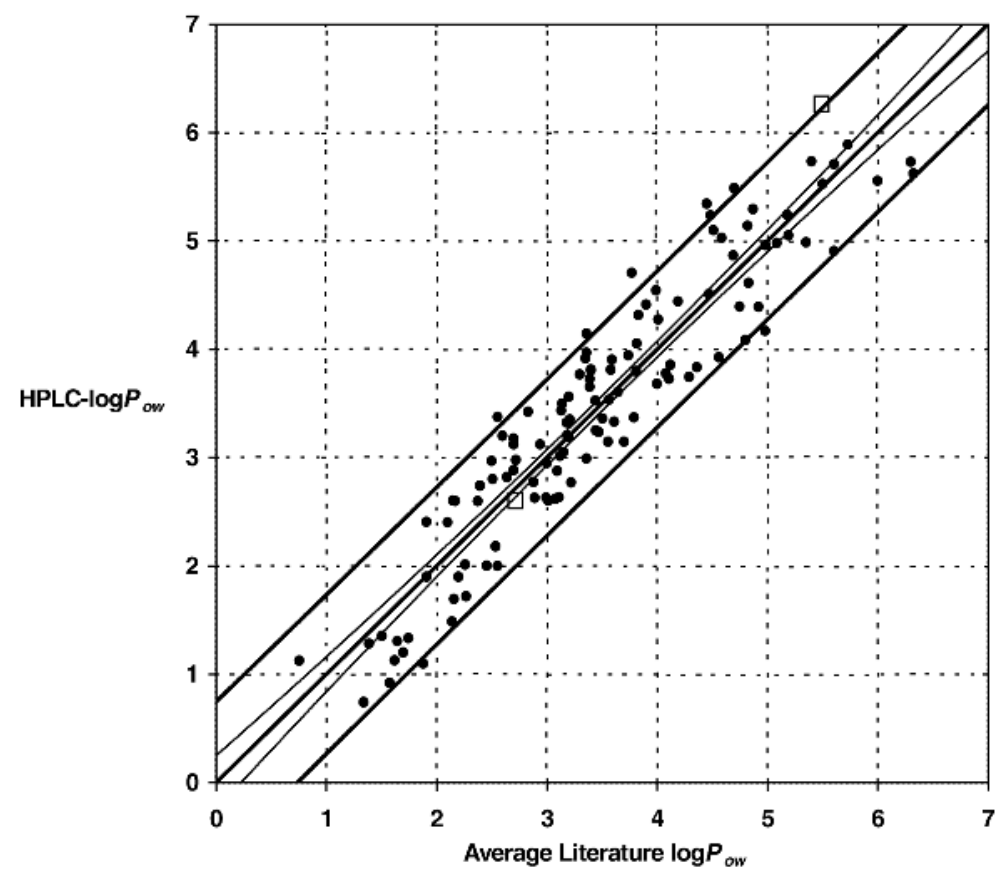

Fig. 2. Average literature $\log \mathrm{P}_{\mathrm{ow}}$ values compared to the HPLC $\log \mathrm{P}_{\mathrm{ow}}$ values. Ninetypercent confidence and prediction intervals displayed. Toluene and triphenylene used as the internal standards. (Donovan \& Pescatore, 2002).

Kaune et al. (Kaune et al., 1998) used gadient HPLC studying s-triazine herbicides and some of their degradation products on RP-18e (LiChrospher) stationary phase with non-linear water-methanol gradient. Though they observed the linearity between retention factors and literature partition coefficient, especially for higher values, better results were obtained for isocratic HPLC with n-octanol coated column and buffered water saturated with n-octanol as the mobile phase. Verbruggen et al. (Verbruggen et al., 1999) also compared isocratic and gradient HPLC in measurements of lipophylicity of organic micropollutants (including pesticides). They used C-18 (Chrompack) column and water-methanol as the mobile phase. In isocratic elution methanol concentration in the effluent was in the range form $80 \%$ to $100 \%$ (with $5 \%$ step) while in linear gradient elution from $50 \%$ to $100 \%$. The results showed linear correlations between chromatographic lipophylicity parameters and partition coefficients calculated from molecular structures of tested substances.

Forgács and Cserháti (Forgács \& Cserháti, 1998) used gradient HPLC on home-made PEE sil (polyethylene-coated silica) column and water-methanol as mobile phase to evaluate lipophylicity of twenty seven commercial urea pesticides. Linear extrapolated $\log \mathrm{k}_{\mathrm{w}}$ and $\mathrm{s}$ parameters were applied as lipophylicity descriptors and analysed by the use of PCA. 
According to results obtained by Forgács and Cserháti, biological activity of pesticides tested cannot be predicted by their behaviour or lipophylicity parameters.

Donovan and Pescatore ((Donovan \& Pescatore, 2002) proposed polymer stationary phase ODP (octadecyl-poly(vinyl alcohol) to determine lipophylicity for a group of 120 bioactive substances, among them 74 commercial fungicides, herbicides and insecticides, using linear gradient from 10 to $100 \%$ methanol in buffer. Chromatographic parameters (HPLC-log $\mathrm{P}_{\text {ow }}$ and retention time) were compared with literature $\log \mathrm{P}_{\mathrm{ow}}$ values (Figure 2 ) as well as with calculated $\log \mathrm{P}_{\mathrm{ow}}$ giving very good results. The authors established the method as a simple, quick, versatile and inexpensive due to: quick gradient and short column $(20 \times 4.0 \mathrm{~mm})$. The additional advantage is the possibility of work at any given $\mathrm{pH}$ value in a wide range between 2 and 13 .

\section{Micellar liquid chromatography}

Micellar liquid chromatography MLC is a mode of conventional RPLC using surfactant solution above critical micellization concentration $(\mathrm{cmc})$ as the mobile phase (MedinaHernándes \& Sagrado, 1995; Garcia-Alvarez-Coque et al., 1997). The presence of micelles in the mobile phase provides a variety of interactions: solute association with the polar head of the surfactant, solute penetration into the micelle core, adsorption of surfactant monomers on the alkyl-bounded stationary phases as a result of hydrophobic interactions between surfactant tail and alkyl chain, and solute interactions with adsorbed surfactant and alkyl chains. The presence of organic modifier influences these interactions - it changes polarity of the bulk phase and cmc. Solvent which can solvate stationary phase reduces the amount of adsorbed surfactant. In such system the retention of solute is governed by three different equilibria: solute distribution between the micelle and the bulk phase, solute partition between the stationary phase and the bulk phase and the direct transfer of solute molecules between surfactant-modified surface and the micelle. The last equilibrium is significant in the case of highly non-polar solutes. MLC is very attractive analytical technique due to the low cost and nontoxicity of surfactant unique selectivity, compatibility of mobile phases with salts and water-insoluble compounds, short equilibrium times in gradient elution the possibility of direct application of biological samples.

Molecular interactions involving solute depend on its lipophylicity and micellar retention parameters and are the source of important information (Medina-Hernándes \& Sagrado, 1995; Foley, 1990). The simplest theoretical retention model in MLC, used in lipophylicity studies, is based on the following relationship:

$$
\frac{1}{\mathrm{k}}=\frac{1}{\mathrm{k}_{\mathrm{m}}}+\frac{\mathrm{K}_{\mathrm{AM}}}{\mathrm{k}_{\mathrm{m}}}[\mathrm{M}]
$$

where $[\mathrm{M}]$ is a total concentration of surfactant in the mobile phase, $\mathrm{K}_{\mathrm{AM}}$ is the constant describing solute-micelle binding, and $\mathrm{k}_{\mathrm{m}}$ is solute retention parameter at zero micellar concentration, i.e. at surfactant monomer concentration equal to cmc. $\mathrm{K}_{\mathrm{AM}}$ and $\mathrm{k}_{\mathrm{m}}$ parameters can be evaluated form the slope and intercept of experimental $1 / k$ vs. [M] relationships determined for three different surfactant concentrations in the mobile phase. In micellar chromatography $\mathrm{k}, \mathrm{k}_{\mathrm{m}}$ and $\mathrm{K}_{\mathrm{Am}}$ parameters, or the logarithms of these values, are used as lipophylicity descriptors and are correlated with $\log \mathrm{P}$ coefficients. The $\mathrm{k}_{\mathrm{m}}$ parameter is considered to be analogical to $\mathrm{k}_{\mathrm{w}}$ index in reversed-phase chromatography. 
Various workers described the usefulness of micellar chromatography for the determination of lipophylicity of different substances (Medina-Hernándes \& Sagrado, 1995; Garcia-Alvarez-Coque et al., 1997; Ruiz-Angel et al., 2004) and some of them observed linear relationships between micellar and partitioning parameters or chromatographic lipophylicity parameters while another reported the curvature of $\log \mathrm{k}$ vs. $\log$ P plots.

Escuder-Gilabert et al. (Escuder-Gilabert et al., 2003) distinguished biopartitioning micellar chromatography BMC, a special case of MLC constituted by C-18 stationary phase and a polyoxyethylene (23) lauryl ether (Brij35) as a surfactant component of the effluent. BMC is helpful in describing the biological behaviour of different kinds of xenobiotics and a main micellar chromatography technique applied in the measurements of various pesticides. This technique was used to predict ecotoxicity of different organic pollutants (also pesticides) (Escuder-Gilabert et al., 2001). Retention parameters measured for buffered 0.06 M Brij35 ( $\mathrm{pH}$ 7.4) were correlated to literature ecotoxicity parameters giving quadratic relationships and afterwards used in QSARs studies.

Bermudez-Saldaña et al. (Bermudez-Saldaña et al., 2005a) using correlated micellar retention parameters of 85 commercial pesticides with fish toxicity and obtained results allowed to classify studied pesticides as harmful, toxic and very toxic. The same authors (BermudezSaldaña et al., 2005b) studied another 85 pesticides from six chemical families, using buffered effluent ( $\mathrm{pH}$ 7.0). Micellar parameters $\log \mathrm{k}$ measured at $0.04 \mathrm{M}$ Brij35 as the mobile phase, proved to be efficient factors in representing the bioconcentration process in fish. Ma et al. (Ma et al., 2006) applied BMC to evaluate micellar log k parameters of 79 heterogenous pesticides used subsequently in QSPR studies.

Biopartitioning micellar chromatography and micellar elektrokinetic chromatography MEKC techniques were compared in the measurements of lipophylic properties of phenoxy acid herbicides (Martin-Biosca et al., 2001). Evaluated retention parameters seemed to be capable of describing and predicting in vitro the toxicity of substances tested.

Modified MEKC, so-called microemulsion electrokinetic chromatography MEEKC, was used by Klotz et al. (Klotz et al., 2001) for the indirect measurements of log P values of over 80 different pesticide compounds. Retention parameters were compared with literature log $\mathrm{P}$ values giving very good linearity. Another modification of MEKC is vesicle electrokinetic chromatography VEKC applied by Klotz et al. (Klotz et al., 2002) for rapid estimation of lipophylic properties of different compounds - among them 43 pesticides. Very high linearity $\left(R^{2}=0.968\right)$ between retention parameters and literature $\log P$ values showed this technique to be very effective in such investigations.

Until now planar techniques with micellar mobile phases are not frequently used for lipophylicity measurements (Shtykov \& Sumina, 2002). In our investigations (Janicka \& Pietras-Ożga, 2010) micellar TLC and OPLC techniques were compared in studying lipophylic properties of eight newly synthesized acetamides applying RP-18W stationary phase and water/Brij35/tetrahydrofuran as the mobile phase. As lipophylicity parameters were proposed micellar retention factors $\log \mathrm{k}$ and $\log \mathrm{k}_{\mathrm{m}}$, which were correlated with $\log \mathrm{P}$ values calculated form molecular structures. Excellent correlations between $\log \mathrm{k}_{\mathrm{m}}$ and $\log \mathrm{P}$ parameters $(\mathrm{R}=0.917-0.987)$ for OPLC results were observed and the results allowed evaluating micellar OPLC as suitable technique - very quick and trustworthy in prediction of lipophilic properties of new compounds. (see Table 3). 


\begin{tabular}{l|cc|cc} 
& \multicolumn{2}{|c|}{ TLC } & \multicolumn{2}{c}{ OPLC } \\
$\log \mathrm{P}$ & $\mathrm{k}_{\mathrm{m}}$ & $\log \mathrm{k}_{\mathrm{m}}$ & $\mathrm{k}_{\mathrm{m}}$ & $\log \mathrm{k}_{\mathrm{m}}$ \\
\hline $\mathrm{IAlog} \mathrm{P}$ & 0.847 & 0.866 & 0.946 & 0.955 \\
$\operatorname{cog} \mathrm{P}$ & 0.937 & 0.952 & 0.918 & 0.925 \\
KowWin & 0.938 & 0.961 & 0.908 & 0.917 \\
$\mathrm{~A} \log \mathrm{P}_{\mathrm{s}}$ & 0.755 & 0.768 & 0.927 & 0.937 \\
$\mathrm{AC} \log \mathrm{P}$ & 0.772 & 0.789 & 0.930 & 0.939 \\
$\mathrm{AB} / \log \mathrm{P}$ & 0.950 & 0.961 & 0.957 & 0.957 \\
milog P & 0.790 & 0.813 & 0.938 & 0.953 \\
$\mathrm{~A} \log \mathrm{P}$ & 0.781 & 0.801 & 0.933 & 0.944 \\
Mlog P & 0.777 & 0.795 & 0.938 & 0.953 \\
xlog $\mathrm{P}_{2}$ & 0.792 & 0.814 & 0.938 & 0.953 \\
x $\log \mathrm{P}_{3}$ & 0.898 & 0.914 & 0.914 & 0.931 \\
$\log \mathrm{P}_{\text {average }}$ & 0.873 & 0.893 & 0.975 & 0.987
\end{tabular}

Table 3. Correlation coefficients $(R)$ obtained for $k_{m}\left(\log k_{m}\right)$ vs. $\log P$ relationships. (Janicka \& Pietras-Ożga, 2010).

\section{BioArena - the method of studying biological activity}

Different parameters determined by reversed-phase liquid chromatography, both column and planar, are correlated with biological activity of commercial pesticides or newly synthesized compounds with potential biological significance. The results obtained by various workers confirm the importance of chromatography in studying lipophylicity or biological activity of pesticides and column and planar chromatography reveal their advantages and limitations. Apart from these applications planar chromatography is a unique technique enable to study the mechanism of action of different bioactive compounds. BioArena, a complex system of chromatographic and biological investigations, creates such possibilities.

BioArena was invented and developed by Hungarian scientists led by E. Tyihák (Tyihák et al., 2003; Tyihák et al., 2004b). This complex analytical system was preceded by extensive investigations on enzymatic methylation-demethylation processes and the role of formaldehyde $\mathrm{HCHO}$ in the biosphere. The studies demonstrated that formaldehyde is an endogenous component of all biological units and that there is a primary $\mathrm{HCHO}$ cycle in this system. Formaldehyde is an indispensable component of all cells and its reaction products play a fundamental role in different biological processes (Ahmad, 1995: Tyihák et al., 1998a; 1998c). The scientists introduced the term "formaldehydome" (Tyihák et al., 1998b; 2005; Tyihák et al., 2008b) which means: "the complete set of HCHO-cycle mediated and non-mediated $\mathrm{HCHO}$ pathways of a given biological unit (including the HCHO cycle itself) as the most important HCHO pathway" and being the part of the biological system." BioArena can aid understanding the mechanism of toxic action of different bioactive compounds - drugs or poisons. It's a combination of bioautography (Botz et al., 2001) and planar chromatography techniques (TLC, HPTLC or OPLC) making possible to examine the 
mechanism of toxicity of substances tested directly on the plate, after chromatographic separation. The basic elements of BioArena are presented on Figure 3 (Tyihák et al., 2004b). Bioautography, the first step of the system, is a very sensitive and selective method for visualization of bioactive compounds after chromatographic separation. Microorganisms can be easy applied to the plate, by immersion or spraying, and the inhibition or promotion of growth in the spots can be visualized by dying living cells. As the next stage postchromatographic investigations are performed: in the adsorbent bed are possible interactions between microbes and co-factor molecules added to the culture medium (Tyihák et al., 2003; 2004b). Co-factors added to the cell culture influence formaldehyde level: capture compounds (e.g. L-arginine or glutathione) decrease HCHO level while promoters (e.g. $\mathrm{Cu}^{2+}$ ions) enhance the antibacterial activity of HCHO (Tyhák et al., 2004a). BioArena makes possible not only the arrangement of all processes on the layer, but also visual and spectroscopic evaluation of the results and even extending the monitoring time for several days (Tyhák et al., 2004b; Tyhák et al., 2005).

BioArena was used to investigate the mechanism of biological action of different substances such as trans-resveratrol and chamomile extracts (Tyhák et al., 2008a), aflatoxins (Móricz et a., 2007; 2008a; 2008b), paclitaxel (Tyhák et al., 2008b), ascorbigens (Kátay et al., 2009).

\section{BASIC ELEMENTS OF BIOARENA}

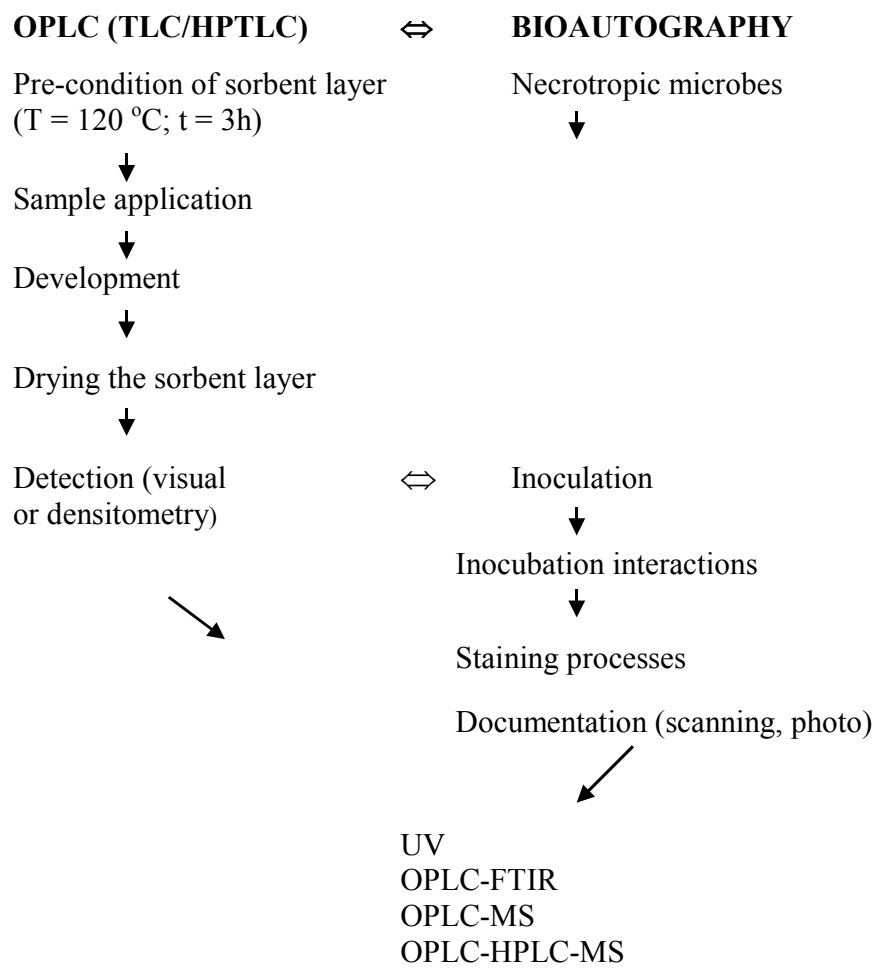

Fig. 3. Combination of off-line OPLC with bioautography and interactions. (Tyhák et al., 2004b). 
In our investigations BioArena system was applied for studying the mechanism of action of 13 newly synthesized potential herbicides - acetamides and chlorophenoxy derivatives (Janicka et al., 2008). At the end of chromatographic separation the plates with substances tested were dried and immersed in the bacterial suspensions. Bacterial biotest was conducted on Pseudomonas savastanoi pv. Phaseolicola race 6, which causes halo blight on beans. After bioauthography detection five substances demonstrating toxicity against Pseudomonas, were chosen for further investigations. Plates with these substances were immersed into bacterial suspensions enriched in L-arginine or reduced glutathione (formaldehyde captures) or $\mathrm{Cu}^{2+}$ ions (formaldehydr promoter). After incubation dry plates were visualized by immersing for 5 minutes in aqueous solution of 3-(4,5-dimethylthiazol-2yl)-2,5-diphenyltetrazolium bromide and Triton-100. Living bacterial cells cause the plate violet color while bright spots (killed bacteria) confirm toxicity of given compound against Pseudomonas.

A

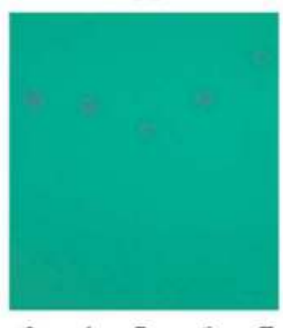

3456

D

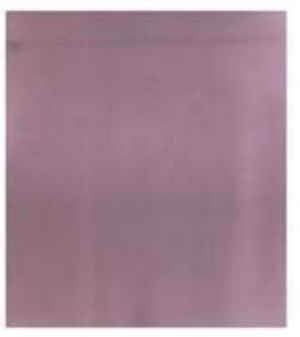

$345 \quad 6 \quad 7$
B

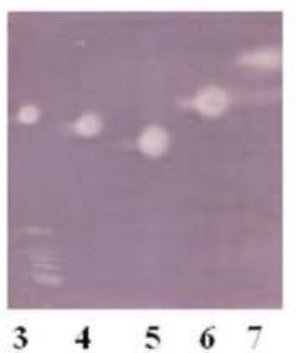

E

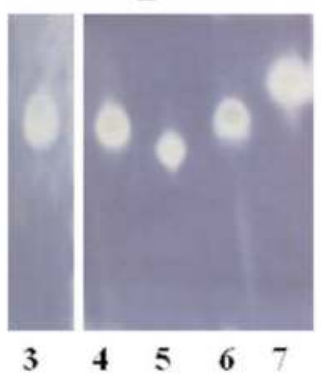

Fig. 4. Solutes 3-7 developed with heptane-1,2-dichloroethane before (A) and after (B) biological detection, and the effects of L-arginine (C),glutathione (D), and Cu2+ ions (E) on the antibacterial activity of the compounds. (Janicka et al., 2008). 
The photos presented on Figure 4 and densitograms on Figure 5 show that L-arginine reduced while glutathione completely inhibited antibacterial activity of the substances. The effect of $\mathrm{Cu}^{2+}$ ions is also unambiguous: copper ions dramatically increase toxicity. These phenomena are visible only in the spots, not on the whole plate, and must be connected with compounds tested. The investigations confirm the mechanism of toxic action as connected with $\mathrm{HCHO}$ cycle and formaldehydome system. In the study biochemical informations were correlated with chromatographic lipophylicity parameters $\log \mathrm{k}_{\mathrm{w}}$ calculated by numerical method from TLC measurements.

The BioArena system is convenient, inexpensive and easy to do experimental method for studying different bioactive compounds, especially newly synthesized, and is a real alternative to animal experimentation.

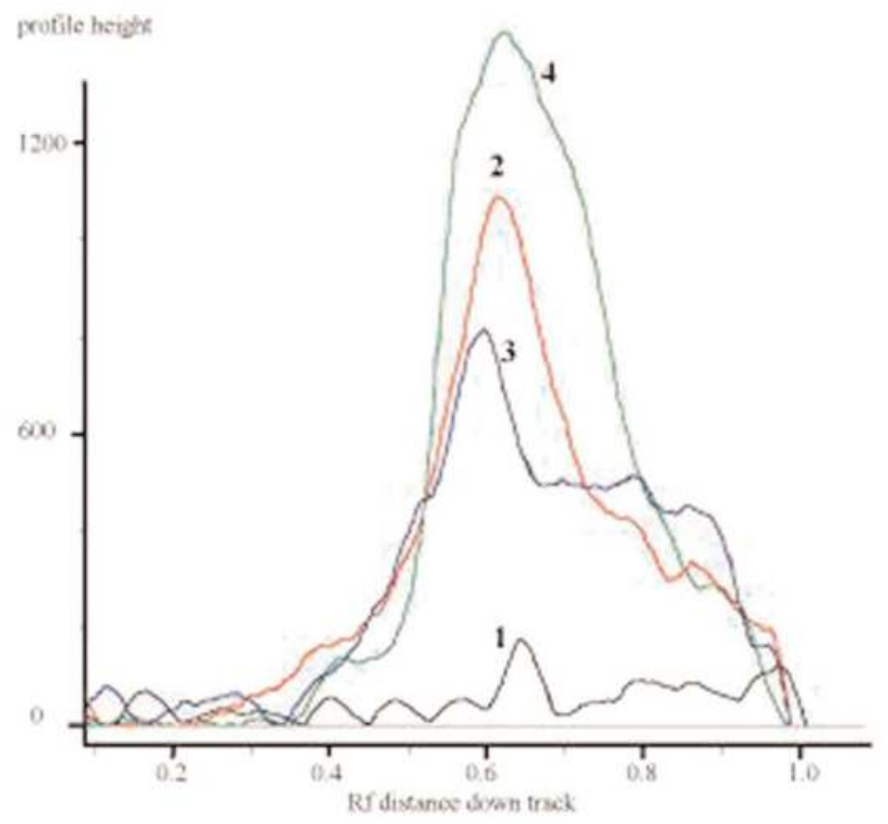

Fig. 5. Densitograms obtained from solute no. 1 before (trace 1) and after (trace 2) biological detection, and the effects of L-arginine (trace 3) and $\mathrm{Cu} 2+$ ions (trace 4 ) on the antibacterial activity of the compound. (Janicka et al., 2008). 


\section{Conclusions}

Liquid chromatography, at the first place very effective separation technique, is more and more often accepted in different outside separation applications. Reversed-phase liquid chromatography is very useful and reliable in studying lipophylic properties of different bioactive compounds like pesticides. The advantages of chromatographic evaluation of lipophylic properties of such substances are beyond dispute. In Table 3 there are summarized applications of different RP LC techniques, i.e. column with isocratic and gradient elution and planar chromatography, as well as techniques applying micellar mobile phases, from last two decades, related to pesticides - commercial and newly synthesized. In the case of new substances being at the stage of investigations and with potential significance in industry or agriculture, chromatographic techniques seems to be especially attractive. They are the source of interesting and valuable informations about solute lipophylicity, structural properties, partition or even biological activity.

Though chromatographic lipophylicity indices are recognized as standard parameters characterizing new bioactive substance, they are not universal. In chromatographic measurements various stationary and mobile phases are used and systematical studies could produce a large chromatographic lipohylicity database similar to log P values.

So far micellar techniques, very attractive in lipophylicity studies due to simplicity and short analysis time, are not very popular in studying pesticides.

Special attention should be paid to BioArena, the system combining separation with biological investigations. BioArena was with great success used to investigate different active substances but so far only occasionally for pesticides.

\begin{tabular}{|l|l|l|}
\hline $\begin{array}{l}\text { compounds } \\
\text { investigated }\end{array}$ & \multicolumn{1}{l|}{ chromatographic system } \\
\hline isocratic reversed-phase column chromatography RP HPLC & Ref. \\
\hline herbicides & RP-18/water-methanol & Braumann et al., 1983 \\
pesticides & RP-18/water-methanol & Hsieh and Dorsey, 1995 \\
$\begin{array}{l}\text { herbicides, fungicides } \\
\text { insecticides, }\end{array}$ & RP-18/water-methanol \\
$\begin{array}{l}\text { herbicides, fungicides, } \\
\text { growth regulators } \\
\text { herbicides, fungicides, } \\
\text { acaricides, insecticides }\end{array}$ & RP-18/water-methanol & Cserháti \& Forgács, 1997 \\
urea pesticides & RP-18/water-methanol \\
herbicides & RP-18/water-acetonitrile & Zhang et al., 2000 \\
pesticides & RP-18/water-methanol & Cserháti \& Forgács, 1994 \\
\hline
\end{tabular}




\begin{tabular}{|c|c|c|}
\hline $\begin{array}{l}\text { compounds } \\
\text { investigated }\end{array}$ & chromatographic system & Ref. \\
\hline $\begin{array}{l}\text { herbicides, fungicides, } \\
\text { insecticides }\end{array}$ & soil/water-methanol & Xu et al. [31] \\
\hline pesticides & ODS, RP-CN, soils/different effluents & $\begin{array}{l}\text { Bermúdez-Sadaña et al. } \\
2006\end{array}$ \\
\hline phenylureas & $\begin{array}{l}\text { C-18-PS- } \mathrm{ZrO}_{2} / \text { water-methanol } \\
\text { RP-18/water-methanol }\end{array}$ & Xia et al., 2005 \\
\hline carbamates & RP-18/water-methanol (1:1, v/v) & $\begin{array}{l}\text { Yamagami \& Katashiba, } \\
1996\end{array}$ \\
\hline biphenyls & RP-18/water-methanol $(4: 1, \mathrm{v} / \mathrm{v})$ & De Kock \& Lord, 1987 \\
\hline s-triazines & $\begin{array}{l}\text { RP-18/water-methanol } \\
\text { RP-18/water-acetonitrile }\end{array}$ & Janicka et al., 2006 \\
\hline thiobenzanilides & different systems & $\begin{array}{l}\text { Niewiadomy et al., } 1998 \\
\text { Jóźwiak, } 2000 \\
\text { Jóźwiak et al., } 2006\end{array}$ \\
\hline acetanilides & RP-18/water-methanol & $\begin{array}{l}\text { Djaković-Sekulić et al., } \\
2001\end{array}$ \\
\hline triazoles & RP-18/water-methanol & Perišić-Janjić et al., 2000 \\
\hline triazoles & RP-18/buffered dioxane ( $\mathrm{pH} 3.5)$ & Sztanke et al., 2008 \\
\hline thiazoles & $\begin{array}{l}\text { RP-18/buffered methanol (pH } 4.0 \text { and } \\
7.4 \text { ). }\end{array}$ & Matysiak et al., 2004 \\
\hline thioamides & RP-18/water-methanol & Kostecka et al., 2005 \\
\hline s-triazines & $\begin{array}{l}\text { n-octanol coated column/ buffer } \\
\text { saturated with n-octanol }\end{array}$ & Kaune et al., 1998 \\
\hline \multicolumn{3}{|c|}{ gradient reversed-phase column chromatography } \\
\hline s-triazines & RP-18e/water-methanol & Kaune et al., 1998 \\
\hline pesticides & RP-18/water-methanol & Verbruggen et al., 1999 \\
\hline pesticides & $\mathrm{PEE}_{\text {sil }} /$ water-methanol & Forgács \& Cserháti, 1998 \\
\hline $\begin{array}{l}\text { fungicides, herbicides, } \\
\text { insecticides }\end{array}$ & ODP/buffered methanol & $\begin{array}{l}\text { Donovan \& Pescatore, } \\
2002\end{array}$ \\
\hline
\end{tabular}




\begin{tabular}{|c|c|c|}
\hline $\begin{array}{l}\text { compounds } \\
\text { investigated }\end{array}$ & chromatographic system & Ref. \\
\hline \multicolumn{3}{|c|}{ reversed-phase planar chromatography } \\
\hline $\begin{array}{l}\text { herbicides, fungicides } \\
\text { insecticides, herbicides }\end{array}$ & RP-18/water-methanol & Darwish et al., 1993 \\
\hline $\begin{array}{l}\text { fungicides, } \\
\text { growth regulators }\end{array}$ & RP-18/water-methanol & Zhang et al., 2000 \\
\hline $\begin{array}{l}\text { herbicides, fungicides, } \\
\text { acaricides, insecticides }\end{array}$ & alumina/n-hexane-dioxan & Cserháti \& Forgács, 1994 \\
\hline $\begin{array}{l}\text { urea pesticides } \\
\text { pesticides }\end{array}$ & $\begin{array}{l}\text { RP-18W/water-methanol } \\
\text { soil/water-methanol }\end{array}$ & $\begin{array}{l}\text { Pyka \& Miszczyk, } 2005 \\
\text { Ravanel et al., } 1999\end{array}$ \\
\hline pesticides & $\begin{array}{l}\text { silica, soil, mixed layers/different } \\
\text { effluents }\end{array}$ & Mohammad et al., 2001 \\
\hline s-triazines & different systems & $\begin{array}{l}\text { Perišić-Janjić et al., 2001; } \\
\text { 2003a; 2003b; } 2005\end{array}$ \\
\hline s-triazines & RP-8 and RP-18/different effluent & Janicka et al., 2004 \\
\hline thiobenzanilides & different systems & $\begin{array}{l}\text { Janicka et al., 2000; } 2006 \\
\text { Matysiak et al., } 1999\end{array}$ \\
\hline acetanilides & starch, cellulose/different effluents & $\begin{array}{l}\text { Djaković-Sekulić et al., } \\
1987\end{array}$ \\
\hline triazoles & $\begin{array}{l}\text { silica gel impregnated with paraffin } \\
\text { oil/water-methanol }\end{array}$ & Perišić-Janjić et al. 2000 \\
\hline thiazoles & RP-8 and RP-18W/different effluents & Matysiak et al., 2002 \\
\hline acetamides & RP-8/water-methanol & Cipman et al., 1998 \\
\hline acetamides & $\begin{array}{l}\text { silica gel impregnated by paraffin } \\
\text { oil/different effluents }\end{array}$ & $\begin{array}{l}\text { Djaković-Sekulić et al., } \\
2002\end{array}$ \\
\hline acetamides & RP-18/different effluents & Perišić-Janjić et al., 2007 \\
\hline acetamides & $\begin{array}{l}\text { RP-18/buffered methanol (pH 5.3, } 7.3 \\
\text { and 8.3) }\end{array}$ & Janicka et al., 2004 \\
\hline thioamides & RP-18/water-methanol & Kostecka et al., 2005 \\
\hline
\end{tabular}




\begin{tabular}{|c|c|c|}
\hline $\begin{array}{l}\text { compounds } \\
\text { investigated }\end{array}$ & chromatographic system & Ref. \\
\hline \multicolumn{3}{|c|}{ liquid chromatography with micellar mobile phases } \\
\hline pesticides & BMC: RP18/buffered Brij35 (pH 7.4) & $\begin{array}{l}\text { Escuder-Gilabert et al., } \\
2001\end{array}$ \\
\hline pesticides & BMC: RP18/buffered Brij35 (pH 7.0) & $\begin{array}{l}\text { Bermudez-Saldaña et al., } \\
\text { 2005a }\end{array}$ \\
\hline pesticides & BMC: RP-18/water-Brij35 & Ma et al., 2006 \\
\hline herbicides & BMC: RP-18/ water-Brij35 & $\begin{array}{l}\text { Y. Martín-Biosca et al., } \\
2001\end{array}$ \\
\hline acetamides & $\begin{array}{l}\text { TLC MLC: RP-18W/ } \\
\text { water-Brij35-tetrahydrofuran }\end{array}$ & $\begin{array}{l}\text { Janicka \& Pietras-Ożga, } \\
2010\end{array}$ \\
\hline pesticides & MEEKC & Klotz et al., 2001 \\
\hline pesticides & VEKC & Klotz et al., 2002 \\
\hline
\end{tabular}

Table 3. Application of different liquid chromatography techniques in lipophylicity measurements of different commercial and newly synthesized pesticides

\section{References}

Ahmad, S. (1995). Oxidative stress and antioxidant defenses in Biology. (Ed.: S. Ahmad), New York, Springer 1995, 0412039710

Balaban, A.T.; Motoc, L.; Bonchev, D. \& Mekenyan, O. (1983). Topological inices for structure-activity correlations. Steric effects in drug design. (Eds.: M. Charton \& I. Motoc), Springer, Toppics Curr. Chem., 114, (1983) 21-55, 0340-1022

Bermúdez-Sadaña, J.M.; Escuder-Gilabert, L.; Medina-Hernández, M.J.; VillanuevaCamañas, R.M. \& Sagrado, S. (2006). Chromatographic estimation of the soilsorption coefficients of organic compounds. Trends in Anal Chem., 25, 2 (February 2006) 122-132, 0165-9936

Bermudez-Saldaña, J.M.; Escuder-Gilabert; L.; Medina-Hernández, M.J.; VillanuevaCamañas, R.M. \& Sagrado, S. (2005). Chromatographic evaluation of the toxicity in fish of pesticides. J. Chromatogr. B, 814, 1 (January 2005) 115-125, 1570-0232

Bermudez-Saldaña, J.M.; Escuder-Gilabert, L.; Medina-Hernández, M.J.; VillanuevaCamañas, R.M. \& Sagrado, S. (2005). Modelling bioconcentration of pesticides in fish using biopartitioning micellar chromatography. J. Chromatogr. A, 1063, 1-2 (January 2005) 153-160, 0021-9673

Biagi, G.L.; Barbaro, A.M.; Sapone, A. \& Recanatini, M. (1994). Determination of lipophilicity by means of reversed-phase thin-layer chromatography : II. Influence of the organic modifier on the slope of the thin-layer chromatographic equation. J. Chromatogr. A, 669, 1-2 (May 1994) 246-253, 0021-9673 
Botz, L.; Nagy, S. \& Kocsis, B. (2001). Detection of microbiologically active compounds, In: Planar chromatography - A retrospective view for the third millennium, (Ed.: Sz. Nyiredy) pp. 489-516, Springer, Budakalász, Hungary , 963699157 X

Braumann, T.; Weber, G. \& Grimme, H. (1983). Quantitative structure-activity relationships for herbicides : Reversed-phase liquid chromatographic retention parameter, $\log \mathrm{k}_{\mathrm{w}}$, versus liquid-liquid partition coefficient as a model of the hydrophobicity of phenylureas, s-triazines and phenoxycarbonic acid derivatives. $J$. Chromatogr. A, 261, (1983) 329-343, 0021-9673

Carrupt, P.-A.; Gaillard, P.; Billois, F.; Weber, P.; Testa, B.; Meyer, C. \& Pérez, S. (1996). The Molecular Lipophilicity Potential (MLP): A New Tool for log P Calculations and Docking, and in Comparative Molecular Field Analysis (CoMFA). In: Lipophylicity in Drug Action and Toxicology. (Eds: V. Pliška et al.) pp. 195-217, Willey-VCH Inc. 1996, 978-3527293834

Cimpan, G.; Irimie, F. \& Gocan, S. (1998). Prediction of the lipophilicity of some Nhydroxyethylamides of aryloxyalkylene and pyridine carboxylic acids by reversedphase thin-layer chromatography. J. Planar Chromatogr.,11, 5 (September 1998) 342345, 0933-4173

Cserháti, T. \& Forgács, E. (1994). Relationship between the high-performance liquid and thin-layer chromatographic retention of non-homologous series of pesticides on an alumina support. J. Chromatogr. A, 668, 1-2 (May 1994) 495-500, 0021-9673

Cserháti, T. \& Forgács, E. (1997). Relationship between the hydrophobicity and specific hydrophobic surface area of pesticides determined by high-performance liquid chromatography compared with reversed-phase thin-layer chromatography. $J$. Chromatogr. A, 771, 1-2 (May 1997) 105-109, 0021-9673

Darwish, Y.; Cserháti, T. \& Forgács, E. (1993). Relationship between lipophilicity and specific hydrophobic surface area of a non-homologous series of pesticides. J. Planar. Chromatogr., 6, (1993) 458-462, 0933-4173

Djaković-Sekulić, T.L. \& Perišić-Janjić, N.U. (2007). Comparative study of the retention of striazines on octadecylsilica, cyano, and amino HPTLC plates by use of a QSPR model. J. Planar Chromatogr., 20, 5 (October 2007) 365-371, 0933-4173

Djaković-Sekulić, T.L.; Perišić-Janjić, N.U. \& Petrović, S.D. (1997). The retention behavior of some anilides on unconventional TLC supports. J. Planar Chromatogr., 10, 4 (July 1997) 298-304, 0933-4173

Djaković-Sekulić, T.L.; Perišić-Janjić, N.U. \& Petrović, S.D. (2002). Normal- and reversedphase chromatography of para-substituted propanoic acid amides. J. Planar Chromatogr., 15, 4 ( July 2002) 274-279, 0933-4173

Djaković-Sekulić, T.L.,; Petrović, S.M.; Perišić-Janjić, N.U. \& Petrović, S.D. (2001). HPLC behavior and hydrophobic parameters of some anilides. Chromatographia, 54, 1-2 (July 2001) 60-64, 0009-5893

Djaković-Sekulić, T.L.; Perišić-Janjić, N.U. \& Pyka, A. (2003). Correlation of retention of anilides and some molecular descriptors. Application of topological indexes for prediction of log k values. Chromatographia, 58, 1-2 (July 2003) 47-51, 0009-5893

Djaković-Sekulić, T.L.; Smoliński, A.; Perišić-Janjić, N.U. \& Janicka M. (2008). Chemometric characterization of (chromatographic) lipophilicity parameters of newly 
synthesized s-triazine derivatives. J. Chemometrics, 22, 3-4 (March-April 2008) 195202, 1099-128X

Donovan, S.F. \& Pescatore, M.C. (2002). Method for measuring the logarithm of the octanolwater partition coefficient by using short octadecyl-poly(vinyl alcohol) highperformance liquid chromatography columns J. Chromatogr. A, 952, 1-2 (April 2002) 47-61, 0021-9673

Du, C.M.; Valkó, K.; Bevan, C.; Reynolds, D. \& Abraham, M.H. (2001). Rapid gradient RPHPLC method for lipophylicity determination: a solvation equation based comparison with isocratic method. Anal. Chem., 70, 20, (October 1998) 4228-4234, 0003-2700

Ellgehausen, H.; D’Hondt, C. \& Fuerer, R. (1981). Reversed-phase chromatography as a general method for determining octan-1-ol/water partition coefficients. Pest. Sci., 12, 2 (April 1981) 219-227, 1526-4998

Escuder-Gilabert, L.; Martín-Biosca, Y.; Sagrado, S.; Villanueva-Camañas, R.M. \& MedinaHernández, M.J. (2001). Biopartitioning micellar chromatography to predict ecotoxicity. Anal. Chim. Acta, 448, 1-2 (December 2001) 173-185, 0003-2670

Escuder-Gilabert, L.; Martínez-Pla, J.J.; Sagrado, S.; Villanueva-Camañas, R.M. \& MedinaHernández, M.J. (2003). Biopartitioning micellar separation methods: modelling drug absorption J. Chromatogr. B, 797, 1-2, (November 2003) 21-35, 1570-0232

Foley, J.P. (1990). Critical compilation of solute-micelle binding constants and related parameters from micellar liquid chromatographic measurements. Anal. Chim. Acta, 231, (1990) 237-247, 0003-2670

Folkers, G. \& Merz, A. (1996). Hydrophobic Fields in Quantitative Structure-Activity Relationships. In: Lipophylicity in Drug Action and Toxicology. (Eds: V. Pliška et al.) pp. 219-232, Willey-VCH Inc. 1996, 978-3527293834

Forgács, E. \& Cserháti, T. (1998). Use of principal component analysis for studying the separation of pesticides on polyethylene-coated silica columns. J. Chromatogr. A, 797, 1-2 (February 1998) 33-39, 0021-9673

Garcia-Alvarez-Coque, M.C.; Torres-Lapasió, J.R. \& Baeza-Baeza, J.J. (1997). Modelling of retention behaviour of solutes in micellar liquid chromatography. J. Chromatogr. A, 780, 1-2 (September 1997) 129-148, 0021-9673

Gocan, S.; Cimpan, G. \& Comer, J. (2005). Lipophylicity Measurements by Liquid Chromatography, in: Advances in Chromatography, vol. 44 (Eds: E. Grushka, N. Grinberg), pp. 79-176, Taylor \& Francis Group 2005, 1574447343

Héberger, K. (2007). Quantitative -structure (chromatographic) retention relationships. J. Chromatogr. A, 1158, 1-2 (July 2007) 273-305, 0021-9673

Hsieh, M.-M. \& Dorsey, J.G. (1995). Bioavailability estimation by reversed-phase liquid chromatography: High bonding density C-18 phases for modeling biopartitioning processes. Anal. Chem., 67, 1 (January 1995) 48-57, 0003-2700

Janicka, M. (2003). Use of OPLC to study the biological activity of organic compounds. Chromatographia, 57, 5-6, (March 2003) 395-403, 0009-5893

Janicka, M. (2006). Comparison of different properties - $\log P, \log k_{w}$ and $\varphi_{o}-$ as descriptors of the hydrophobicity of some fungicides. J. Planar Chromatogr., 19, 111 (October, 2006) 361-370, 0933-4173 
Janicka, M. (2007). Use of thin-layer and over-presured layer chromatography to study the hydrophobicity of homologous s-trazines. J. Planar Chromatogr., 20, 4 (September 2007) 267-274, 0933-4173

Janicka, M. (2009). Application of Ościk's equation for description of solute retention in RP HPLC and calculation of retention factor in water. J. Liquid Chromatogr. \& Rel. Technolog., 32, 19 (January 2009) 2779-2794, 1082-6076

Janicka, M.; Kwietniewski, L. \& Matysiak, J. (2000). A new method for estimations $\log \mathrm{k}_{\mathrm{w}}$ values and solute biological activity. J. Planar Chromatogr., 13, 4 (July/August, 2000) 285-289, 0933-4173

Janicka, M.; Kwietniewski, L. \& Perišić-Janjić, N.U. (2006). Determination of retention factors of s-triazines homologous series in water using numerical method basing on Ościk's equation. Chromatographia, 63, Supp. 13 (June 2006) S87-S93, 0009-5893

Janicka, M.; Ościk-Mendyk, B. \& Tarasiuk, B. (2004a). Planar chromatography in studies of the hydrophobic properties of some new herbicides. J. Planar Chromatogr., 17, 3 (June 2004) 186-191, 0933-4173

Janicka, M.; Perišić-Janjić, N.U. \& Różyło, J.K. (2004b). Thin-layer and over-pressured layer chromatography for evaluation of the hydrophobicity of s-triazine derivatives. J. Planar Chromatogr., 17, 100 (December 2004) 468-475, 0933-4173

Janicka, M. \& Pietras-Ożga, D. (2010). Chromatographic evaluation of lipophilicity of Nphenyl-trichloroacetamide derivatives using micellar TLC and OPLC. J. Planar Chromatogr., 23, 6 (December 2010) 396-399, 0933-4173

Janicka, M. \& Różyło, J.K. (2003). OPLC and TLC in the prediction of retention factors of solutes in pure water. Proc. Inter. Symp. On Planar Separation, Planar Chromatography 2003 (Ed. Sz. Nyiredy), pp. 13-23, Budapest, Hungary, June 2003, Research Institute for Medicinal Plants, Budakalász, Hungary

Janicka, M.; Tyihák, E.; Móricz, Á. \& Ościk-Mendyk, B. (2008). Crucial role of formaldehyde and its reaction products in the antiproliferative activity of some potential pesticides. J. Planar Chromatogr., 21, 3, (June 2008) 161-166, 0933-4173

Jaroniec, M. (1993). Partition and displacement models in reversed-phase liquid chromatography with mixed eluents. J. Chromatogr. A, 656, 1-2 (December 1993) 3750, 0021-9673

Jóźwiak, K.; Szumiło, H.; Sęczyna, B. \& Niewiadomy, A. (2000). RPHPLC as a tool for determining the congenericity of a set of 2,4-dihydroxythiobenzanilide derivatives. Chromatographia, 52, 3-4 (August 2000) 159-161, 0009-5893

Kah, M. \& Brown, C.D. (2008). Log D: Lipophilicity for ionisable compounds. Chemosphere, 72, 10 (August 2008) 1401-1408, 0045-6535

Kaliszan, R. (1987). Quantitative Structure-Chromatographic Retention Relationships, New York, John Willey \& sons 1987, 0471859834

Kaliszan, R. (1992). Quantitative structure-retention relationships. Anal. Chem., 64, 11 (June 1992) 619A-631A, 0003-2700

Kátay, G.; Ott, P.G.; Kátay, E.,; Magyar, D. \& Tyihák, E. (2009). Potential role of formaldehyde in the mechanism of action of ascorbigens on the basis of BioArena studies. Biomed. Chromatogr., 23, 4 (2009) 412-417, 0269-3879 
Kaune, A.; Brüggemenn, R. \& Kettrup, A. (1998). High-performance liquid chromatographic measurement of the 1-octanol-water partition coefficient of s-triazine herbicides and some of their degradation products. J. Chromatogr. A, 805, 1-2 (May 1998) 119126, 0021-9673

Klotz, W.; Schure, M.R. \& Foley, J.P. (2001). Determination of octanol-water partition coefficients of pesticides by microemulsion electrokinetic chromatography. J. Chromatogr. A, 930, 1-2 (September 2001) 145-154, 0021-9673

Klotz, W.; Schure, M.R. \& Foley, J.P. (2002). Rapid estimation of octanol-water partition coefficients using synthesized vesicles in electrokinetic chromatography. J. Chromatogr. A, 962, 1-2 (July 2002) 207-219, 0021-9673

De Kock, A.C. \& Lord, D.A. (1987). A simple procedure for determining octanol-water patition coefficients using reverse phase high performance liquid chromatography (RPHPLC). Chemosphere, 16, 1 (1987) 133-142, 0045-6535

Komsta, Ł.; Skibiński, R.; Berecka, A.; Gumieniczek, A.; Radkiewicz, B. \& Radoń, M. (2010). Revisiting thin-layer chromatography as a lipophylicity determination tool- a comparative study on several techniques with a model solute set. J. Pharm. Biomed. Anal., 53, 4 (December 2010) 911-918, 0731-7085

Kostecka, M.; Niewiadomy, A. \& Czeczko, R. (2005). Evaluation of N-Substituted 2,4Dihydroxyphenylthioamide Fungicide Lipophilicity Using the Chromatographic Techniques HPLC and HPTLC. Chromatographia, 62, 3-4 (August 2005) 121-126, 0009-5893

Krieger, R.J. (2001). Handbook of Pesticide Toxicology. Principles. USA, Elsevier 2001, 978-0-12426260-7

Lipiński, C.A.; Lombardo, F.; Dominy, B.W. \& Feeney, P.J. (2001). Experimental and computational approaches to estimate solubility and permeability in drug discovery and development settings. Adv. Drug Delivery Rev., 46, 1-3 (March 2001) 3-26, 0169-409X

Ma, W.; Luan, F.; Zhang, H.; Zhang, X.; Liu, M.; Hu, Z. \& Fan, B. (2006). Quantitative structure-property relationships for pesticides in biopartitioning micellar chromatography. J. Chromatogr. A, 1113, 1-2 (April 2006) 140-147, 0021-9673

Martín-Biosca, Y.; Escuder-Gilabert, L.; Marina, M.L.; Sagrado, S. \& Villanueva-Camañas, R.M. (2001). Quantitative retention- and migration-toxicity relationships of phenoxy acid herbicides in micellar liquid chromatography and micellar electrokinetic chromatography. Anal Chim. Acta, 443, 2 (September 2001) 191-203, 0003-2670

Matysiak, J.; Niewiadomy, A.; Sęczyna, B. \& Różyło, J.K. (2004). Relationships Between LC Retention, Octanol-Water Partition Coefficient, and Fungistatic Properties of 2-(2,4Dihydroxyphenyl)benzothiazoles. J. AOAC Int., 87, 3 (2004) 579-586, 1060-3271

Matysiak, J.; Niewiadomy, A.; Żabińska, A. \& Różyło, J.K. (1999). Structure and retention of 2,4-dihydroxythiobenzanilides in a reversed-phase system. J. Chromatogr. A, 830, 2, (January 1999) 491-496, 0021-9673

Matysiak, J.; Żabińska, A.; Różyło, J.K. \& Niewiadomy, A. (2002). Determination of the lipiophylicity of bioactive 2-phenylbenzothiazoles by RPTLC. J. Planar Chromatogr., 15, 5 (October 2002) 380-383, 0933-4173 
Medina-Hernándes, M.J. \& Sagrado, S. (1995). Chromatographic quantification nof hydrophobicity using micellar mobile phases. J. Chromatogr. A, 718, 2 (December 1995) 273-282, 0021-9673

Mohammad, A.; Khan, I.A. \& Jabeen, N. (2001). Thin-layer chromatographic studies of the mobility of pesticides through soil-containing static flat-beds. J. Planar Chromatogr., 14, 4 (August 2001) 283-242, 0933-4173

Móricz, Á.; Adányi, N.; Horváth, E.; Ott, P.G. \& Tyihák, E. (2008a). Applicability of BioArena system to investigation of the mechanism of biological effects. J. Planar Chromatogr., 21, 6 (December 2008) 417-422, 0933-4173

Móricz, Á.; Horváth, E.; Ott, P.G. \& Tyihák, E. (2008b). Raman spectroscopic evaluation of the influence of Pseudomonas bacteria on aflatoxin B1 in the BioArena complex bioautographic system. J. Raman Spectrosc., 39, 10 (2008) 1332-1337, 1097-4555

Móricz, Á.; Ott, P.G.; Billes, F.; Otta, K.H. \& Tyihák, E. (2007). The influence of L-ascorbic acid on the antibacterial-toxic activity of aflatoxins on adsorbent layer. J. Appl. Microbiol., 103, 6 (December 2007) 2525-2532, 1365-2672

Nasal, A.; Siluk, D. \& Kaliszan, R. (2003). Chromatographic retention parameters in medicinal chemistry and molecular pharmacology. Curr. Med. Chem., 10, 5 (March 2003) 381-426, 0929-8673

Niewiadomy, A.;, Matysiak, J.; Żabińska, A.; Różyło, J.K.; Sęczyna, B. \& Jóźwiak, K. (1998). Reversed-phase high-performance liquid chromatography in quantitative structure-activity relationship studies of new fungicides. J. Chromatogr. A, 828, 1-2 (December 1998) 431-438, 0021-9673

Nurok, D. (1989). Strategies for optimizing the mobile phase in planar chromatography Chem. Rev., 89, 2 (March 1989) 363-375, 0009-2665

Perišić-Janjić, N.U.; Ačanski, M.M.; Janjić, N.J.; Lazarević, M.D. \& Dimova, V. (2000). Study of the lipophilicity of some 1,2,4-triazole derivatives by RPHPLC and TLC. J. Planar Chromatogr., 13, 4 (July/August 2000) 281-284, 0933-4173

Perišić-Janjić, N.U.; Djaković-Sekulić, T.L.; Jevrić, L.L. \& Jovanović, B.Ž. (2005). Study of quantitative structure-retention relationships for s-triazine derivatives in different RP HPTLC systems. J. Planar Chromatogr., 18, 103 (May 2005) 212-216, 0933-4173

Perišić-Janjić, N.U.; Djaković-Sekulić, T.L. \& Popov-Pergal, K. (2004). Correlation between the structures of some 2,4-dioxotetrahydro-1,3-thiazoles and TLC retention data. J. Planar Chromatogr., 17, 3 (May 2004) 192-199, 0933-4173

Perišić-Janjić, N.U.; Djaković-Sekulić, T.L. \& Ušćumlić, G.S. (2002). Normal- and reversedphase TLC of N-phenylsuccinimide derivatives. J. Planar Chromatogr., 15, 4 (July 2002) 294-298, 0933-4173

Perišić-Janjić, N.U.; Jevrić, L.L.; Bončić- Carčić, G. \& Jovanović, B.Ž. (2001). Study of the lipophilicity and retention behavior of some s-triazine derivatives on aminoplast and cellulose. J. Planar Chromatogr., 14, 4 (August 2001) 277-282, 0933-4173

Perišić-Janjić, N.U. \& Jovanović, B.Ž. (2003). Reverse-phase thin-layer chromatographic behavior of some s-triazine derivatives. J. Planar Chromatogr., 16, 1 (January 2003) 71-75, 0933-4173

Perišić-Janjić, N.U.; Jovanović, B.Ž.; Janjić, N.J.; Rajković, O.S. \& Antonović, D.G. (2003). Study of the retention behavior of newly synthesized s-triazine derivatives in RP 
TLC systems, and the lipophilicity of the compounds. J. Planar Chromatogr., 16, 6 (November 2003) 425-432, 0933-4173

Perišić-Janjić, N.U. \& Podunavac-Kuzmanović, S.O. (2008). RPTLC study of QSRR and QSAR for some benzimidazole derivatives. J. Planar Chromatogr., 21, 2 (April 2008) 135-141, 0933-4173

Perišić-Janjić, N.U.; Vastag, G.; Tomić, J. \& Petrović, S. (2007). Effect of the physicochemical properties of $\mathrm{N}, \mathrm{N}$-disubstituted-2- phenylacetamide derivatives on their retention behavior in RP-TLC. J. Planar Chromatogr., 20, 5 (October 2007) 353-359, 0933-4173

Pietrogrande, M.C.; Borea, P.A.; Guerra, M.C. \& Biagi, G.L. (1985). Relationship between log $\mathrm{k}^{\prime \prime}$ values of benzodiazepines and composition of the mobile phase J. Liquid Chromatogr. \& Rel. Technol., 8, 9 (July 1985) 1711-1729, 1082-6076

Poole, S.K. \& Poole, C.F. (2003). Separation methods for estimating octanol-water partition coefficients. J. Chromatogr. B, 797, 1-2 (November 2003) 3-19, 1570-0232

Poppe, H. (1993). Distribution isoterms in reversed-phase system. J. Chromatogr. A, 656, 1-2 (December 1993) 19-36, 0021-9673

Pyka, A. \& Miszczyk, M. (2005). Chromatographic Evaluation of the Lipophilic Properties of Selected Pesticides. Chromatographia, 61, 1-2 (January 205) 37-42, 0009-5893

Ravanel, R.; Liégeois, M.H.; Chevallier, D. \& Tissut, M. (1999). Soil thin-layer chromatography and pesticide mobility through soil microstructures: New technical approach. J. Chromatogr. A, 864, 1 (December 1999) 145-154, 0021-9673

Ruiz-Angel, M.J.; Carda-Broch, S.; García-Alvarez-Coque, M.C. \& Berthod, A. (2004). Micellar versus hydro-organic mobile phases for retention -hydrophobicity relationship studies with ionizable diuretics and anionic surfactant. J. Chromatogr. A, 1030, 1-2 (March 2004) 279-288, 0021-9673

Sangster, J. (1997). Octanol-Water Partition Coefficients: Fundamentals and Physical Chemistry. New York 1997, John Willey \& sons, 0471973971

Sherma, J. (2003). Recent Advances in the Thin-Layer Chromatography of Pesticides: A Review. J. AOAC Int., 86, 3 (2003) 602-611, 1060-3271

Shtykov, S.S.; Sumina, E.G. \& Tyurina, N.Y. (2002). Calculation of Partition Coefficients of Organic Reagents in Micellar Thin-Layer Chromatography. J. Anal. Chem., 57, 4 (2002) 322-325, 1061-9348

Tyihák, E.; Albert, L.; Németh, Zs.; Kátay, Gy.; Király-Véghely, Zs. \& Szende, B. (1998a). Formaldehyde cycle and the natural formaldehyde generators and capturers. Acta Biol. Hung., 49, 2-4 (1998) 225-238, 0236-5383

Tyihák, E.; Botz, L.; Ott, P.G.; Nagy, S.; Kocsis, B.; Király-Véghely, Zs. \& Mincsovics, E. (2003). The Combination of the Overpressured Layer Chromatography and Bioautography and Its Applications to the Analysis of Molecules Influencing Cell Proliferation. Chem. Anal., 48, (2003) 543-553

Tyihák, E. \& Mincsovics, E. (2001). Over-pressured-layer chromatography (optimum performance laminar chromatography) (OPLC), In: Planar Chromatography - A Retrospective View for the Third Millennium, (Ed.: Nyiredy Sz.) pp. 489-516, Springer, Budapest, Hungary, 963699157 X

Tyihák, E.; Minscovics; E.; Kátay, Gy.; Király-Véghely; Zs.; Móricz; Á. \& Ott, P.G. (2008a). BioArena: an unlimited possibility of biochemical interactions in the adsorbent 
layer after chromatographic separation. J. Planar Chromatogr., 21, 1 (February 2008) 15-20, 0933-4173

Tyihák, E.; Móricz, Á. \& Ott, P.G. (2004a). Role of formaldehydome in antibiotic effect: new approach to mechanism of antibiotic action of some metal ions. In: Metal Ions in Biology and Medicine: vol. 8. (Eds.: Cser, M.A. et al.), pp. 131-134, John Libbey Eurotext, Paris

Tyihák, E.; Móricz, Á.; Ott, P.G.; Hajnos, M.L. \& Głowniak, K. (2008b). New approach to mechanism of action of paclitaxel by means of BioArena Studies. J. Planar Chromatogr., 21, 5 (October 2008) 331-336, 0933-4173

Tyihák, E.; Móricz, Á.; Ott, P.G.; Kátay, G. \& Király-Véghely, Zs. (2005). The potential of BioArena in the study of the formaldehydome. J. Planar Chromatogr., 18, 101 (February 2005) 67-72, 0933-4173

Tyihák, E.; Ott, P.G.; Móricz, Á.; Kátay, Gy. \& Király-Véghely, Zs. (2004b). Antibiosis, antibiotics, and the formaldehyde cycle: The unique importance of planar chromatographic techniques to progress in these fields. J. Planar Chromatogr., 17, 2 (April 2004) 84-88, 0933-4173

Tyihák, E.; Trézl, L. \& Szende, B. (1998b). Formaldehyde cycle and the phases of stress syndrome. Ann. N. Y. Acad. Sci., 851, (1998) 259-270, DOI: 10.1111/j.17496632.1998.tb09001.x

Sztanke, K.; Tuzimski, T.; Rzymowska, J.; Pasternak, K. \& Kendefer-Szerszeń, M. (2008). Synthesis, determination of the lipophilicity, anticancer and antimicrobial properties of some fused 1,2,4-triazole derivatives. Eur. J. Med. Chem., 43, 2 (February 2008) 404-419, 0223-5234

Valkó, K. \& Slegel, P. (1993). New chromatographic hydrophobicity index $\left(\phi_{\mathrm{o}}\right)$ based on the slope and the intercept of the $\log k^{-}$versus organic phase concentration plot. J. Chromatogr., 631, 1-2 (February 1993) 49-61, 0021-9673

Valkó, K. HPLC applications in physicochemical measurements, In: Handbook of HPLC, vol. 78, (Eds: E. Katz et al.), pp. 859-902, New York 1998, Marcel Dekker Inc. 0-82479444-3

Valkó, K., Bevan, C. \& Reynolds, D. (1997). Chromatographic hydrophobicity index by fastgradient RP-HPLC: A high-throughput alternative to $\log$ P/log D. Anal. Chem., 69, 11 (June 1997) 2022-2029, 0003-2700

Valkó, K. (2004). Application of high-performance liquid chromatography based measurements of lipophylicity to model biological distribution. J. Chromatogr. A, 1037, 1-2 (May 2004) 299-310, 0021-9673

Wang, Q.S. \& Zhang, L. (1999). Review of research on quantitative structure-retention relationships in thin-layer chromatography. J. Liquid Chromatogr. \& Rel. Technol., 22, 1 (January 1999) 1-14, 1082-6076

Van de Waterbeemd, H.; Kansy, M.; Wagner, B. \& Fisher, H. (1996). Lipophylicity measurements by reversed-phase high performance liquid chromatography (RPHPLC). In: Lipophylicity in Drug Action and Toxicology. (Eds: V. Pliška et al.) pp. 7387, Willey-VCH Inc. 1996, 978-3527293834

Verbruggen, E.M.J.; Klamer, H.J.C.; Villerius, L.; Brinkman U.A.Th. \& Hermens, J.L.M. (1999). Gradient elution reversed-phase high-performance liquid chromatography 
for fractionation of complex mixtures of organic micropollutants according to hydrophobicity using isocratic retention parameters. J. Chromatogr. A, 835, 1-2 (March 1999) 19-27, 0021-9673

Xia, Y.; Guo, Y.; Wang, H.; Wang, Q. \& Zuo, Y. (2005). Quantitative structure-retention relationships of benzoylphenylureas on polystyrene-octadecene-encapsulated zirconia stationary phase in reversed-phase high performance liquid chromatography. J. Sep. Sci., 28, 1 (January 2005) 73-77, 1615-9314

Xu, F.; Liang, X.; Lin, B.; Su, F.; Schramm, K.-W. \& Kettrup, A. (1999). Soil column chromatography for correlation between capacity factors and soil organic partition coefficients for eight pesticides. Chemosphere, 39, 13, (December 1999) 2239-2248, 0045-6535

Yamagami, C. \& Katashiba, N. (1996). Hydrophobicity parameters determined by reversedphase liquid chromatography. Prediction of $\log \mathrm{P}$ values for phenyl N-methyl and phenyl N,N-dimethylcarbamates. Chem. Pharm. Bull., 44, 7 (1996) 1338-1343, 00092363

Zhang, L.; Zhang, M.; Wang. L.X. \& Wang. Q.S. (2000). Relationship between the lipophilicity and specific hydrophobic surface area of some pesticides by RP-HPLC and HPTLC. Chromatographia, 52, 5-6 (September 2000) 305-308, 0009-5893

Zięba, A. \& Prus; W. (2009). Determination of the lipophylicity of new azaphenothiazines by reversed-phase thin-layer chromatography. Acta Chromatogr., 21, 3 (2009) 369378, 1233-2356 


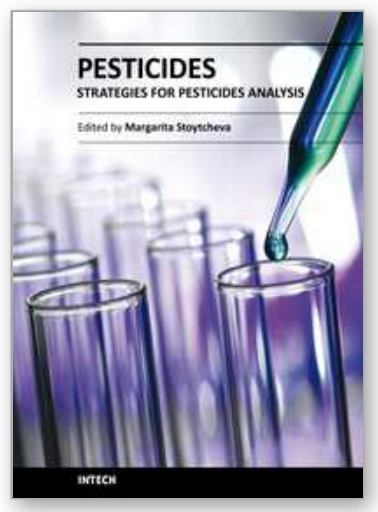

\author{
Pesticides - Strategies for Pesticides Analysis \\ Edited by Prof. Margarita Stoytcheva
}

ISBN 978-953-307-460-3

Hard cover, 404 pages

Publisher InTech

Published online 21, January, 2011

Published in print edition January, 2011

This book provides recent information on various analytical procedures and techniques, representing strategies for reliability, specificity, selectivity and sensitivity improvements in pesticides analysis. The volume covers three main topics: current trends in sample preparation, selective and sensitive chromatographic detection and determination of pesticide residues in food and environmental samples, and the application of biological (immunoassays-and biosensors-based) methods in pesticides analysis as an alternative to the chromatographic methods for "in situ" and "on line" pesticides quantification. Intended as electronic edition, providing immediate "open access" to its content, the book is easy to follow and will be of interest to professionals involved in pesticides analysis.

\title{
How to reference
}

In order to correctly reference this scholarly work, feel free to copy and paste the following:

Małgorzata Janicka (2011). Liquid Chromatography in Studying Lipophylicity and Bioactivity of Pesticides, Pesticides - Strategies for Pesticides Analysis, Prof. Margarita Stoytcheva (Ed.), ISBN: 978-953-307-460-3, InTech, Available from: http://www.intechopen.com/books/pesticides-strategies-for-pesticides-analysis/liquidchromatography-in-studying-lipophylicity-and-bioactivity-of-pesticides

\section{INTECH}

open science | open minds

\section{InTech Europe}

University Campus STeP Ri

Slavka Krautzeka 83/A

51000 Rijeka, Croatia

Phone: +385 (51) 770447

Fax: +385 (51) 686166

www.intechopen.com

\section{InTech China}

Unit 405, Office Block, Hotel Equatorial Shanghai

No.65, Yan An Road (West), Shanghai, 200040, China 中国上海市延安西路65号上海国际贵都大饭店办公楼 405 单元

Phone: +86-21-62489820

Fax: $+86-21-62489821$ 
(C) 2011 The Author(s). Licensee IntechOpen. This chapter is distributed under the terms of the Creative Commons Attribution-NonCommercialShareAlike-3.0 License, which permits use, distribution and reproduction for non-commercial purposes, provided the original is properly cited and derivative works building on this content are distributed under the same license. 